INTERNATIONAL FOOD

POLICY RESEARCH INSTITUTE

sustainable solutions for ending hunger and poverty

Supported by the CGIAR

IFPRI Discussion Paper 00992

June 2010

\title{
Impact of Farmer Field Schools on Agricultural Productivity and Poverty in East Africa
}

\author{
Kristin Davis \\ Ephraim Nkonya \\ Edward Kato \\ Daniel Ayalew Mekonnen \\ Martins Odendo \\ Richard Miiro \\ Jackson Nkuba
}

Knowledge, Capacity, and Innovation Division 


\section{INTERNATIONAL FOOD POLICY RESEARCH INSTITUTE}

The International Food Policy Research Institute (IFPRI) was established in 1975. IFPRI is one of 15 agricultural research centers that receive principal funding from governments, private foundations, and international and regional organizations, most of which are members of the Consultative Group on International Agricultural Research (CGIAR).

\section{PARTNERS AND CONTRIBUTORS}

IFPRI gratefully acknowledges the generous unrestricted funding from Australia, Canada, China, Denmark, Finland, France, Germany, India, Ireland, Italy, Japan, the Netherlands, Norway, the Philippines, South Africa, Sweden, Switzerland, the United Kingdom, the United States, and the World Bank.

\section{AUTHORS}

Kristin Davis, International Food Policy Research Institute

Research Fellow, Knowledge Capacity and Innovation Division

k.davis@cgiar.org

Ephraim Nkonya, International Food Policy Research Institute

Senior Research Fellow, Environment and Production Technology Division

Edward Kato, International Food Policy Research Institute

Research Analyst, Environment and Production Technology Division

Daniel Ayalew Mekonnen, International Food Policy Research Institute

Research Officer, Knowledge Capacity and Innovation Division

Martins Odendo, Kenya Agricultural Research Institute

Researcher

Richard Miiro, Makerere University

Lecturer, Department of Agricultural Extension/Education, Faculty of Agriculture

Jackson. Nkuba, Maruku Agricultural Research Institute

Researcher

\section{Notices}

${ }^{1}$ Effective January 2007, the Discussion Paper series within each division and the Director General's Office of IFPRI were merged into one IFPRI-wide Discussion Paper series. The new series begins with number 00689, reflecting the prior publication of 688 discussion papers within the dispersed series. The earlier series are available on IFPRI's website at http://www.ifpri.org/publications/results/taxonomy\%3A468.

2 IFPRI Discussion Papers contain preliminary material and research results. They have been peer reviewed, but have not been subject to a formal external review via IFPRI's Publications Review Committee. They are circulated in order to stimulate discussion and critical comment; any opinions expressed are those of the author(s) and do not necessarily reflect the policies or opinions of IFPRI.

Copyright 2010 International Food Policy Research Institute. All rights reserved. Sections of this material may be reproduced for personal and not-for-profit use without the express written permission of but with acknowledgment to IFPRI. To reproduce the material contained herein for profit or commercial use requires express written permission. To obtain permission, contact the Communications Division at ifpri-copyright@cgiar.org. 


\section{Contents}

Acknowledgments $\quad$ vi

Abstract vii

Abbreviations and Acronyms viii

1. Introduction 1

2. Background to the Study 2

3. Methodological Approach 4

4. Results 9

5. Conclusions and Policy Implications 30

Appendix A: Balancing Tests 33

Appendix B: Value of Crop Production before and after FFS 36

$\begin{array}{ll}\text { References } & 40\end{array}$ 


\section{List of Tables}

1. Household sampling $\quad 8$

2. Participation in FFSs across gender and level of education (based on individual membership) 10

3. Determinants of participation in FFSs (probit regressions with village fixed effects) 11

4. Reasons for not joining an FFS (\%) 12

5. Impact of FFS participation on value of crop productivity in Kenya (Kenyan shillings) 14

6. Impact of FFS participation on value of crop productivity in Tanzania (Tanzanian shillings) 15

7. Impact of FFS participation on crop productivity in Uganda (Ugandan shillings) 15

8. Impact of FFS participation on value of crop productivity per acre in East Africa (U.S. dollars) 16

9. Impact of FFS participation on livestock income in Kenya (Kenyan shillings) 20

10. Impact of FFS participation on livestock income in Tanzania (Tanzanian shillings) 20

11. Impact of FFS participation on livestock income in Uganda (Ugandan shillings) 21

12. Impact of FFS participation on livestock income in all countries (U.S. dollars) 21

13. Impact of FFS participation on agricultural income per capita in Kenya (Kenyan shillings) 24

14. Impact of FFS participation on agricultural income per capita in Tanzania (Tanzanian shillings) 25

15. Impact of FFS participation on agricultural income per capita in Uganda (Ugandan shillings) 25

16. Impact of FFS on agricultural income per capita in all countries (U.S. dollars) 26

A.1. Kenya 33

A.2. Tanzania $\quad 34$

A.3. Uganda $\quad 35$

B.1. Kenya

B.2. Tanzania

$\begin{array}{ll}\text { B.3. Uganda } & 37\end{array}$

B.4. Impact of FFSs in Kenya

B.5. Impact of FFSs in Tanzania 38

B.6. Impact of FFSs in Uganda 38

B.7. Impact of FFSs, all countries $\quad 39$ 


\section{List of Figures}

1. IFAD-FAO FFS project districts 3

2. Measuring the impact of FFS participation $\quad 6$

3. Impact of FFS participation on value of crops produced per acre 14

4. Impact of FFS participation on crop productivity across gender of household head (\%

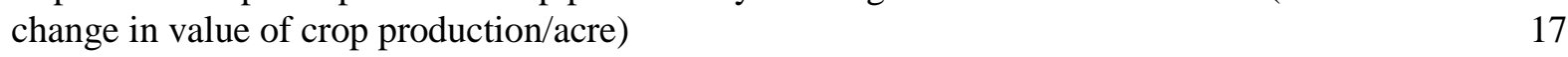

5. Impact of FFS participation on crop productivity across land poverty terciles 17

6. Impact of FFS participation on crop productivity across education levels of household head 18

7. Impact of FFS participation on livestock production across gender of household head (\%
change in value of livestock per household)

8. Impact of FFS participation on livestock production across land poverty terciles 22

9. Impact of FFS participation on livestock production across education level of household head 23

10. Impact of FFS participation on per capita agricultural income across countries 24

11. Impact of FFS participation across gender of household head (\% change in agricultural income $\begin{array}{ll}\text { per capita) } & 27\end{array}$

12. Impact of FFS participation on agricultural income across land poverty terciles 27

13. Impact of FFS participation on agricultural income across education level of household head 28

14. Impact of FFS participation on value of crops produced per acre, livestock value gain per capita, and agricultural income per capita 


\section{ACKNOWLEDGMENTS}

This study was supported by the International Fund for Agricultural Development.

Special thanks to Deborah Duveskog, Godrick Khisa, James Okoth, Julianus Thomas, Martins Odendo, Richard Miiro, Jackson Nkuba, Geofrey Lubade, Eriasaph Owere, Pudentiana Mitti, Hyasinta K. Mutagulwa, Serapion P. Bachubile, Dennis S. Ndamugoba, Joranda Ishengoma, Paschal Mutensa, Davis Kazaura, Leonidas J. Rwezaula, Agripina Zawadi Mutalemwa, Rwegoshora M. Wilson, Ruth Blasio Ishabakaki, Georgina Rweikiza, Deodigard H. Muchunguzi, Lukas Peter Kamugisha, Noelina Kokushubila Rutalemwa, John Inganga, Ruth Apondi, Joseph Otieno, Henry Mukongolo, Jared Wandete, Susan Wanyela, George Akhulo, Emma Obuya, George Otando, Pulton Ochieno, Joseph Agaja, Grace Asio, Raymond E. Ebulu, John Elibu, John Emongor, William Ependuno, J. Jarangah, Lydia Nafula, James Ndiywa, James Odieny, Ojwang Olopot, and R.O.E. Osara. 


\begin{abstract}
Farmer field schools (FFSs) are a popular education and extension approach worldwide. Such schools use experiential learning and a group approach to facilitate farmers in making decisions, solving problems, and learning new techniques. However, there is limited or conflicting evidence as to their effect on productivity and poverty, especially in East Africa. This study is unique in that it uses a longitudinal impact evaluation (difference in difference approach) with quasi-experimental methods (propensity score matching and covariate matching) together with qualitative approaches to provide rigorous evidence to policymakers and other stakeholders on an FFS project in Kenya, Tanzania, and Uganda. The study provides evidence on participation in FFSs and on the effects of FFSs on various outcomes.

The study found that younger farmers who belong to other groups, such as savings and credit groups, tended to participate in field schools. Females made up 50 percent of FFS membership. Reasons for not joining an FFS included lack of time and information. FFSs were shown to be especially beneficial to women, people with low literacy levels, and farmers with medium-size land holdings. FFS participants had significant differences in outcomes with respect to value of crops produced per acre, livestock value gain per capita, and agricultural income per capita. FFSs had a greater impact on crop productivity for those in the middle land area (land poverty) tercile.

Participation in FFSs increased income by 61 percent when pooling the three countries. FFSs improved income and productivity overall, but differences were seen at the country level.

Participation in FFSs led to increased production, productivity, and income in nearly all cases: Kenya, Tanzania, and at the project level (all three countries combined). The most significant change was seen in Kenya for crops (80 percent increase) and in Tanzania for agricultural income (more than 100 percent increase). A lack of significant increases in Uganda was likely due to Uganda's National Agricultural Advisory Services. When disaggregating by gender, however, female-headed households benefited significantly more than male-headed households in Uganda.
\end{abstract}

Key words: farmer field schools, agricultural productivity, adoption, Kenya, Tanzania, Uganda, extension services 


\section{ABBREVIATIONS AND ACRONYMS}

$\begin{array}{ll}\text { AESA } & \text { Agro-ecosystem analysis } \\ \text { ATT } & \text { Average treatment effect on the treated } \\ \text { DD } & \text { Double difference } \\ \text { DiD } & \text { Difference in difference } \\ \text { FAO } & \text { Food and Agriculture Organization of the United Nations } \\ \text { FFS } & \text { Farmer field school } \\ \text { IFAD } & \text { International Fund for Agricultural Development } \\ \text { IFPRI } & \text { International Food Policy Research Institute } \\ \text { IPM } & \text { Integrated pest management } \\ \text { IPPM } & \text { Integrated pest and production management } \\ \text { MOALD } & \text { Ministry of Agriculture and Livestock Development (Kenya's former } \\ & \text { ministry) } \\ \text { NGO } & \text { Nongovernmental organization } \\ \text { PSM } & \text { Propensity score matching }\end{array}$




\section{INTRODUCTION}

Agricultural education, extension, and advisory services are a critical means of addressing rural poverty, because such institutions have a mandate to transfer technology, support learning, assist farmers in problem solving, and enable farmers to become more actively embedded in the agricultural knowledge and information system (Christoplos and Kidd 2000, 11). Extension is responsible to almost one billion small-scale farmers worldwide. It is thus urgent to seek the best ways to support such farmers in terms of information, technology, advice, and empowerment.

Finding an extension approach is a special challenge in the African context, as poverty is growing and productivity is declining on the continent. Twenty-four African countries have listed extension as one of the top agricultural priorities for a poverty reduction strategy (InterAcademy Council 2004).

One very popular extension and education program worldwide is the farmer field school (FFS) approach, now in place in at least 78 countries (Braun et al. 2006). Started in Indonesia in 1989, FFSs have expanded through many parts of Sub-Saharan Africa. Kenya alone is the site of more than 1,000 such schools with 30,000 farmer graduates (FAO/KARI/ILRI 2003). Many donors, governments, and nongovernmental organizations (NGOs) enthusiastically promote FFSs in Sub-Saharan Africa today. As a result of their popularity, there is some discussion as to whether the FFS approach should be scaled up and out and incorporated into mainstream extension practices (Anandajayasekeram, Davis, and Workneh 2007).

As FFS implementation is being scaled up in Africa, there are growing concerns and interest among stakeholders and donors regarding the applicability, targeting, cost-effectiveness, and impact of the approach. There have been relatively few efforts to document in a systematic manner the impact of FFSs, and therefore extension actors often find themselves with many questions about when, where, and how FFSs should be applied.

Although the FFS approach is a popular method - the new "orthodoxy," according to Leeuwis, Röling, and Bruin (1998) - much of what is written on FFSs is found only in the grey literature and deals mainly with the methodology or cases of FFS approaches. Thus the long-term impacts of FFSs remain unclear. Some of the evidence on those impacts in peer-reviewed journal articles is conflicting. A brief survey of the impact literature includes the World Bank Asian studies (Feder, Murgai, and Quizon 2004a, 2004b; Rola, Jamias, and Quizon 2002) and additional studies in Cameroon (David 2007), Uganda (Erbaugh, Donnermeyer, and Kibwika 2001), Sri Lanka (Tripp, Wijeratne, and Piyadasa 2005), Bolivia (Bentley et al. 2007), and Peru (Ortiz et al. 2004). Reviews of various projects can be found in van den Berg (2004) and van den Berg and Jiggins (2007). Thus, much is still unknown about the approach and the issues pertinent to extension, such as poverty reduction, sustainability, participation, and financing.

To explore and document the East African experience, as well as to provide robust evidence for policymakers, donors, farmers, and implementation actors on whether and how FFSs can contribute to agricultural productivity and poverty alleviation, the International Food Policy Research Institute (IFPRI) and the International Fund for Agricultural Development (IFAD) engaged in a rigorous evaluation of FFSs. The purpose of the study was to improve practice in FFSs and extension education to lead to improved livelihoods of farmers in East Africa, and to provide robust evidence on the impact of FFSs on farmer, project, and national goals. This report provides evidence of the impact of a FFS project implemented in Kenya, Tanzania, and Uganda. 


\section{BACKGROUND TO THE STUDY}

Farmer field schools are traditionally an adult education approach - a method to assist farmers to learn in an informal setting within their own environment. FFSs are "schools without walls" where groups of farmers meet weekly with facilitators. They are a participatory method of learning, technology development, and dissemination (FAO 2001) based on adult learning principles such as experiential learning (Davis and Place 2003).

With the preceding description of what is meant by FFSs in this report, we now discuss FFS implementation in the East Africa region. FFS implementation began in East Africa in 1995 with the Food and Agriculture Organization's (FAO's) Special Programme for Food Security. That program ended in 1998. In 1999, FAO's Global Integrated Pest Management Facility ${ }^{1}$ started the East African Subregional Project for Farmer Field Schools in eight pilot districts in Kenya, Tanzania, and Uganda (Kimani and Mafa n.d.). Supporting the project were the International Fund for Agricultural Development (IFAD), Ministry of Agriculture and Livestock Development $\left(\mathrm{MOALD}^{2}\right)$ and the FAO. The topic was integrated production and pest management (IPPM).

The objectives of the project were to (a) increase the competence of the extension systems to provide farmer education that responds more effectively to local resources and conditions; (b) establish a networking capacity for exchanging FFS experiences within and among African countries; and (c) contribute information on the replicability and effectiveness of the FFS as an alternative and sustainable extension vehicle to IFAD's target groups (IFAD 1998). This first phase of the project ended in 2002.

A second, expansion phase of the project was launched in October 2005 and ran for three years (Food and Agriculture Organization 2005). The goal of the expansion phase was to enhance the livelihoods of farmers in eastern and southern Africa through the development and expansion of a lowcost, sustainable, and broad-based model for farmer education and empowerment (Food and Agriculture Organization 2005, 1). The project aimed to do this through devising self-financing mechanisms, broadening the scope of extension services, encouraging demand-driven and market-oriented services, and strengthening farmer organizations and networks.

For the purposes of this report, the project (both the initial phase and the expansion phase) will be known as the IFAD-FAO FFS project (since the FAO runs multiple FFS projects in the region).

The IFAD-FAO FFS project worked in Busia, Bungoma, and Kakamega districts in Kenya; Bukoba, Muleba, and Missenyi districts in Tanzania; and Busia, Kabermaido, and Soroti districts in Uganda (Figure 1). The areas were chosen based on (a) relevance of crops and farming systems; (b) the need to develop an interface between smallholders and extension activities; (c) testing the FFSs under the new decentralized district governance structures; and (d) the potential linkage with ongoing IFAD extension activities (IFAD 1998).

As stated earlier, there is much unknown about the effects of FFSs on the lives of farmers beyond case studies in one or two districts in one country. The IFAD-FAO FFS project will allow researchers to move beyond a single-country case study to make comparisons of FFSs across several districts and countries. That it is a single project run by one organization in multiple countries helps to account for variables that may affect outcomes such as different implementers' approaches and goals. Furthermore, the IFAD-FAO FFS project is one of the longest-running FFS projects in the region, and baseline data were collected at the beginning of the second phase. This allowed the researchers to conduct a longitudinal study, making it more rigorous and comprehensive than has been done to date in Africa.

\footnotetext{
${ }^{1}$ The Global Integrated Pest Management Facility is funded by the World Bank, FAO, the United Nations Environment Programme, and the United Nations Development Programme. Its mission is to promote adoption of integrated pest management in the developing world.

${ }^{2}$ At the start of the project, this was the name of the ministry. It has since been split into the Ministry of Agriculture and the Ministry of Livestock and Fisheries Development.
} 
The goal of the study presented in this report is to provide robust evidence for policymakers, donors, farmers, and implementation actors on whether and how FFSs can contribute to agricultural productivity and poverty alleviation. The specific objectives of the study are as follows:

1. Examine participation in FFSs, especially the extent to which poor people, women, and other marginalized groups take part in the schools.

2. Examine the effects of FFSs on outcomes such as poverty, gender, and productivity, and the role that household-capital-endowment-level social characteristics have on access and use/maximization of benefits of the FFS approach.

Following the introduction, Section 2 provides a background to the study on farmer field schools. It has described the introduction of FFS to East Africa and the IFAD-FAO FFS project. The following section describes our methodological approach and data sources. Section 4 presents the results of the study according to the two preceding objectives. Finally, Section 5 presents conclusions and policy recommendations.

\section{Figure 1. IFAD-FAO FFS project districts}

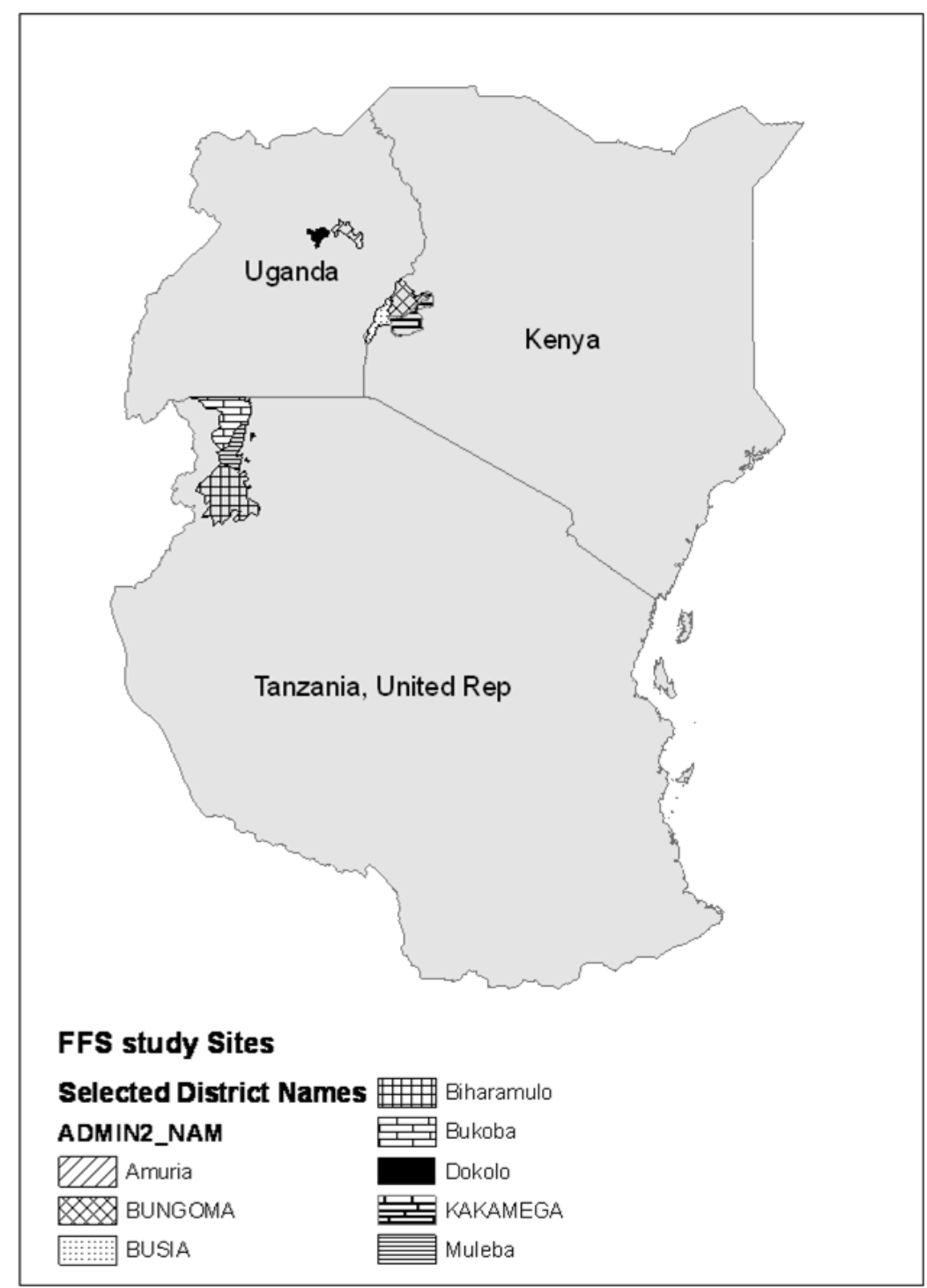

Source: Authors' compilation. 


\section{METHODOLOGICAL APPROACH}

We now turn to the methods used in our study to better understand participation in FFSs, their effects on development outcomes, and the evolution and institutionalization of FFSs in the region.

The study used a variety of methods and approaches to assess FFSs in East Africa. The overall design employed was a longitudinal impact evaluation. Due to the nature of the program and data available, an ex post facto design was used combining a double-difference estimator with matching estimators (propensity score matching and covariate matching). Both qualitative and quantitative methods were used to collect and analyze data, including document analysis, semistructured interviews with key informants, and primary and secondary survey data.

Methods for measuring impacts of programs have developed over the past two decades, and the central question has been the problem of attribution to program interventions (Imbens and Wooldrige 2008). Any outcome that a program aims to change has many other factors that could affect it. This makes it difficult to attribute the impacts to one particular program intervention. For example, if an FFS is implemented in one village and the objective is to measure how the FFS affected adoption of improved crop varieties, there are many other factors that could affect adoption, including other extension programs provided by NGOs, farmers, cooperatives, and other projects and programs. FFS participants could also adopt improved crop varieties not because of the FFS intervention but because other constraints that were limiting adoption have been addressed (for instance, recent high food prices could have provided incentives for farmers to adopt new varieties). In the next section, we discuss impact studies and the difficulty of measuring program effects, before moving on to discuss the quasi-experimental and qualitative means used to collect data.

\section{A Review of Impact Analysis}

As noted in the introduction, only a few studies document FFS impact in a systematic manner and are both rigorous and broad in scope (van den Berg 2004). Because of the paucity of studies, especially in Africa, much remains unknown about the approach and the issues pertinent to extension, such as effectiveness, sustainability, participation, and financing. Before discussing in more depth the particular methods used for this study, the authors first discuss methodological problems and issues.

Among FFS practitioners and researchers, there is little agreement yet as to what to measure, how to measure it, and what the measurements mean with regard to the impacts of FFSs (Braun et al. 2006). There is no agreed-upon conceptual framework for measuring the impact of the schools (van den Berg 2004), and thus the methods of measurement are still under development (van den Berg and Jiggins 2007). Evaluation is complex because of methodological disagreements, diversity of parameters, and different perspectives on impact (van den Berg and Jiggins 2007). Part of the problem is the different approaches of FFSs in general and the specific objectives of local FFSs. Some schools use more of a transfer-of-technology approach, whereas others focus on education or empowerment. Although many case studies have been done and data on FFS outcomes exist, finding a study that is both statistically rigorous yet comprehensive in coverage is hard (van den Berg 2004). As a result, the body of evidence on impacts is small in comparison with the great number of FFS projects worldwide, especially with regard to medium- and long-term impacts (van den Berg and Jiggins 2007).

In the more general extension literature, extension impacts per se are very difficult to show, especially in terms of dealing with attribution issues and linking cause and effect quantitatively (Purcell and Anderson 1997). Many infrastructural variables and other factors affect agricultural performance in complex and contradictory ways, and benefits are difficult to quantify (Anderson 2007; Birkhaeuser, Evenson, and Feder 1991). Measurement challenges of several types contribute to the difficulty, and questions of representativeness occur in any attempt at grouping. Extension as an input is also difficult to measure, and usually proxies are used (Birkhaeuser, Evenson, and Feder 1991). Further problems include lack of baseline data and the inability to include all contributing variables in production equations. 
Impact studies basically face three interrelated challenges: (a) establishing a viable counterfactual (the predicted outcome in the absence of the intervention-i.e., what would have happened to the participants had they not participated in the FFS); (b) attributing the impact to an intervention; and (c) coping with long and unpredictable lag times (Alston and Pardey 2001; Salter and Martin 2001). Other issues that may confound studies include endogeneity in program placement and extension-farmer interactions, farmerto-farmer information flow, selection bias, and policies that affect various measures. Very few studies use an experimental design, and some studies that have used control groups have run into design problems.

Two common sources of bias are program placement or targeting bias, in which the location or target population of the program is not random, and self-selection bias, in which households choose whether or not to participate, and thus may be different in their experiences, endowments, and abilities. employed:

To address the problems of showing impact, generally the following approaches have been

- experimental approaches;

- longitudinal comparisons (or reflexive control) for participants;

- cross-sectional comparisons of participants versus nonparticipants;

- econometrics such as the instrumental variable approach; and

- quasi-experimental and nonexperimental approaches, including

$\circ$ propensity score matching and covariate matching and

○ the double-difference estimator (Smale et al. 2008; Davis and Nkonya 2008).

The most accepted method to address the previously mentioned biases is to use an experimental approach to construct an estimate of the counterfactual situation by randomly assigning households to treatment (participant) and control (nonparticipant) groups. Random assignment ensures that both groups are statistically similar (i.e., drawn from the same distribution) in both observable and unobservable characteristics, thus avoiding program placement and self-selection biases. Such an approach is not feasible in demand-driven programs in which participants make their own decisions of whether to participate and about the kind of activities to do in the learning process. Likewise, random assignment also conflicts with the nature of community-driven development programs like FFSs.

\section{Quasi-experimental Methods}

To address these challenges, several quasi-experimental methods have been developed to net out the impacts of other factors. A common approach is to use panel data that include the baseline data, which measure the outcome before the intervention, and follow-up data that measure the outcome after passage of time deemed sufficient for the impact of the intervention to set in. A two-time-period panel is the minimum requirement, but more frequent collection of data may be necessary depending on the nature of the outcome that is being measured. Ideally, the impact of an intervention needs to be measured with the participants by observing the outcome with and without the intervention. For example, if the outcome is crop yield $(y)$ of the participant, the impact of FFS participation could be measured by observing the yield of the farmers participating in the FFS (participants) and their expected yield if they did not participate in the FFS. This is referred to in the impact literature as the average effect of the treatment on the treated (ATT), that is,

$$
\operatorname{ATT}=\left(y_{1} \mid p=1\right)-\left(y_{0} \mid p=0\right),
$$

where $p=$ participation in the project ( $p=1$ if participated in the project, and $p=0$ if did not participate in the project); $y_{1}=$ yield of the participant after participating in the program; and $y_{0}=$ yield of the same participant if he or she did not participate. According to Figure 2, 


\section{$\mathrm{ATT}=\mathrm{B}-\mathrm{C}$.}

However, $\left(y_{0} \mid p=0\right)=\mathrm{C}$ is unobservable since the participant cannot simultaneously participate and not participate in the FFS. Several methods have been used to find counterfactuals that could be used to measure the equivalent of $\left(y_{0} \mid p=0\right)$. A common approach has been to find a control group that has similar observable characteristics as the participants. The characteristics considered are those that affect participation in the program and outcome of interest. Choice of characteristics that affect the outcomes and the probability to participate in the FFS lowers the bias (Heckman et al. 1998). Figure 2 presents the framework used to measure impacts of interventions.

\section{Figure 2. Measuring the impact of FFS participation}

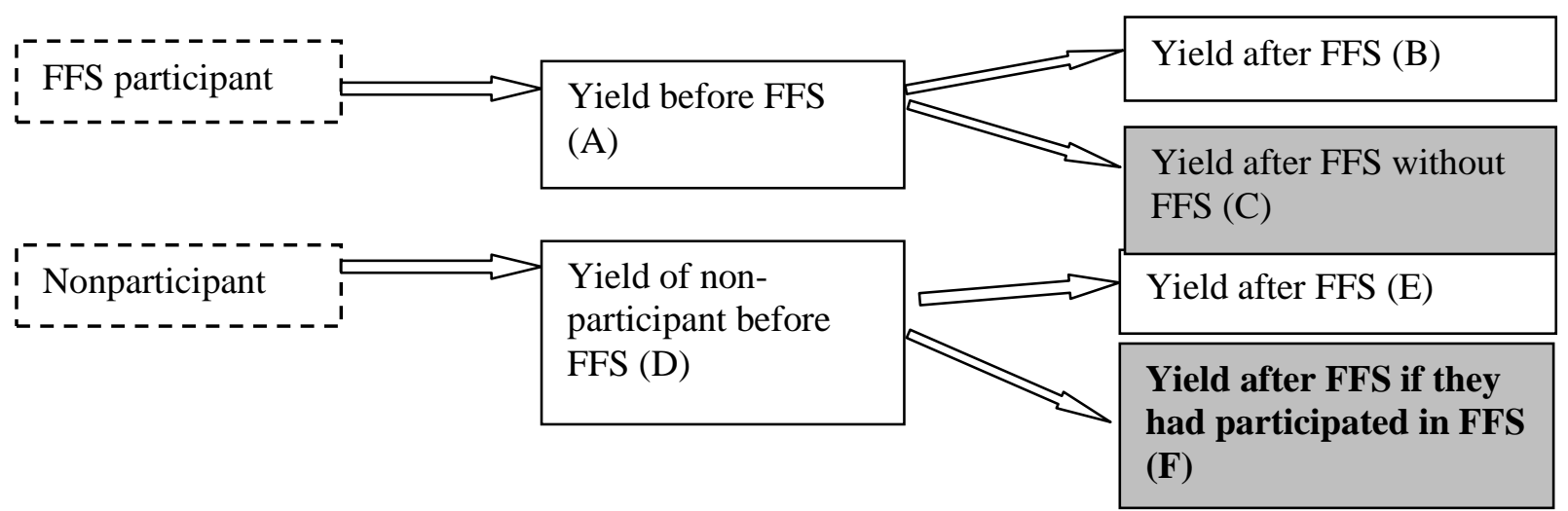

Source: Authors' creation.

Using this control group accounts for other factors that could have also affected yield or any other outcome (Heckman et al. 1998). The impact of other factors that affect the outcome of interest is eliminated by subtracting the changes in yield of FFS nonparticipants before and after FFS from the change in yield of the FFS participants, that is,

$$
\operatorname{ATT}=(A-B)-(E-D) .
$$

Placement of the FFSs in the project area was not random. Nonrandom program placement is a common problem in developing countries (Duflo, Glennerster, and Kremer 2006), and it introduces a placement bias. For example, it is possible to find NGOs and other extension service providers in areas with better market access (Platteau 2004; Jagger and Pender 2006; Rutatora and Mattee 2001). This will tend to overestimate the impact of an FFS due to the favorable market conditions that may lead to higher yields. Random assignment of treatment - a method used to address placement and self-selection bias - is not possible since participation in the FFSs is voluntary. Farmers choose to participate or not participate, depending on their expectations, objectives, and observable and unobservable characteristics that affect participation. This is referred to as "self-selection" in impact literature. For example, farmers with higher levels of education may be more likely to participate in new programs than those with lower levels of education. This means farmers participating in the FFSs may not be representative of the nonparticipants. Several nonexperimental quantitative methods have been developed to address the self-selection bias. The instrumental variable approach eliminates the selection bias problem, but the method is difficult to use because it is difficult to find instruments that affect the probability to participate but do not affect outcome.

Matching methods are also used to address the self-selection bias. Several matching methods have been developed. A commonly used matching method is propensity score matching (PSM), which 
matches the participants and nonparticipants based on the observable characteristics that affect participation in the program and the outcome being measured (Rosenbaum and Rubin 1983; Smith and Todd 2001, 2005). The propensity scores are calculated using equation (3):

$$
\mathrm{P}\left(\mathrm{X}_{\mathrm{i}}\right)=\mathrm{E}\left(\mathrm{Di} \mathrm{X}_{\mathrm{i}}\right)
$$

where $X_{i}$ is a vector of pretreatment covariates, which includes variables that affect both participation in the FFS and outcomes (e.g., yield, income, empowerment, etc.).

$$
\left(0<P\left(\mathrm{X}_{i}\right)<1\right) \text {. }
$$

Where $\mathrm{P}\left(\mathrm{X}_{\mathrm{i}}\right)$ is the probability to participate in FFS. Exact matching on $P\left(X_{i}\right)$ eliminates bias. Several PSM estimators are used. Those commonly used are kernel matching and nearest-neighbor matching. Kernel matching measures treatment effects by subtracting from each outcome observation in the treatment group a weighted average of outcomes in the comparison group. Nearest-neighbor matches participants with nonparticipants with the nearest propensity scores. The nearest-neighbor matching accounts for differences in the mean values of the participants and nonparticipants (Abadie and Imbens 2006, 2007). Nearest-neighbor matching efficiency improves as the number of matches increase. We used these two PSM methods in the analysis. However, matching may not be achieved for some of the covariates used to compute the propensity scores. In such cases, the computed impact of intervention will still be biased. An alternative method is covariate matching, which matches the treated and untreated observations directly using observable variables. Covariate matching does not use propensity scores to match. The major weakness of covariate matching is that it requires many variables - the curse of dimensionality. However, it is robust to bias due to poor matching using PSM. To ensure robustness of the results, we used the three matching methods.

We conducted a balancing test, which tests for differences in the means of the PSM explanatory variables between the matched groups (Dehejia and Wahba 2002). We used bootstrapping to compute the standard errors of the estimated ATT, generating robust standard errors because the matching procedure matched control households to treatment households "with replacement" (see Abadie and Imbens 2002).

Combining matching methods and ATT controls bias due to differences in pre-FFS observable characteristics. A bias could still result from the time-variant variables or the unobservable differences between participants and nonparticipants. Hence we also used qualitative methods to assess the impact of the FFSs. A combination of methods helps to address the shortcomings of impact assessment methods (Duflo, Glennerster, and Kremer 2006).

To improve the precision of matching estimators, we examined the distribution of each of the continuous covariates used in the probit regression using the Shapiro-Wilk and Shapiro-Francia tests of skewness and Kurtosis (Gould and Rogers 1991). Using Tukey's ladder of powers transformation, the logarithmic transformation was identified as the best for achieving normality. Transformation also reduces the effect of outliers and leverage (Mukherjee, White, and Wuyts 1998).

The outcome indicators analyzed using this method were the productivity of crops and livestock, the sectors that the FFSs affected directly. Hence we analyzed the impact of FFSs on crop and livestock productivity and the total value of production from those two sectors. We also analyzed the total value of production of crops and livestock together, which is called simply "agricultural income." It is true that agricultural income would usually include other sectors (such as forestry, beekeeping, fishing, etc.), but the analysis was restricted to crops and livestock, which are the two most important sectors in the region and on which the FFSs focused their activities.

\section{Data}

A household survey was used to analyze the quantitative impact of the FFS project on participants. As Table 1 shows, a total of 1,126 households were randomly selected from villages with FFSs and villages without FFSs. The villages without FFSs were chosen such that they were comparable in terms of 
biophysical (rainfall, topography, etc.) and socioeconomic characteristics (ethnicity, farming systems, etc.). Table 1 gives information about the countries, districts, and numbers of FFS and non-FFS farmers.

This survey was a resampling of respondents from the original baseline survey, conducted in late 2006 (see Alokit-Olaunah 2006; Nkuba, Thomas, and Duveskog 2007; Odendo, Duveskog, and Khisa 2006). The sampling procedure for that study, as described in Nkuba, Thomas, and Duveskog, was a twostage random sampling technique. A list of all newly registered FFSs (as of 2006) in the IFAD-FAO FFS project districts made up the sampling frame. A total of 20 FFSs per country were randomly selected from purposively selected districts. The number of farmers selected was proportional to the number of field schools in each district and diversity of agro-ecological zones. Next, lists of households were used to randomly select household members, the number of members being interviewed being proportional to the total membership in FFSs. For the non-FFS participants, a list was obtained of all villages in the district where the selected FFS households were located. A list of households in each village was drawn up, and households randomly sampled.

The survey instrument was a closed-ended questionnaire that was modified from the baseline survey instrument (to include more data on production and income). It was field-tested during a three-day training exercise with the enumerators and local researchers in each of the three countries.

Data were checked using data-cleaning syntax that checked for errors. Data cleaning was then done at the country level by data assistants.

Due to a lack of baseline data on production and income variables, farmers were asked to report their management practices before participating in the FFS. Farmers had no difficulty remembering the preprogram data since these particular FFSs had been implemented for only two years in all three countries.

Table 1. Household sampling

\begin{tabular}{|c|c|c|c|c|}
\hline \multirow[t]{2}{*}{ Country } & \multirow[t]{2}{*}{ District } & \multicolumn{2}{|c|}{ Number of farmers sampled } & \multirow[t]{2}{*}{ Total } \\
\hline & & FFS farmers & Non-FFS farmers & \\
\hline \multirow[t]{5}{*}{ Kenya } & Butere-Mumias* & 2 & 4 & 6 \\
\hline & Kakamega & 125 & 44 & 169 \\
\hline & Bungoma & 68 & 37 & 105 \\
\hline & Busia & 86 & 32 & 118 \\
\hline & Total & 281 & 117 & 398 \\
\hline \multirow[t]{4}{*}{ Tanzania } & Bukoba & 101 & 39 & 140 \\
\hline & Missenyi* & 35 & 25 & 60 \\
\hline & Muleba & 136 & 43 & 179 \\
\hline & Total & 272 & 107 & 379 \\
\hline \multirow[t]{4}{*}{ Uganda } & Soroti & 83 & 32 & 115 \\
\hline & Kabermaido & 69 & 50 & 119 \\
\hline & Busia & 79 & 36 & 115 \\
\hline & Total & 231 & 118 & 349 \\
\hline Grand total & & & & 1,126 \\
\hline
\end{tabular}

Notes:* These districts were split from the other study districts after the project was implemented. 


\section{RESULTS}

The previous section discussed the methods and approaches used to meet the research objectives. Again, those objectives were as follows:

1. Examine participation in FFSs, especially the extent to which poor people, women, and other marginalized groups take part in the schools.

2. Examine the effects of FFSs on outcomes such as poverty, gender, agricultural productivity, and sustainability of agriculture, and the role that household-capital-endowment-level social characteristics have on access and use/maximization of benefits of the FFS approach.

Note that in Kenya, postelection violence starting in January 2008 could have affected the respondents in many ways, including ethnic violence and attacks upon farms and persons, high costs of food and fuel, and government administration (through personnel having to flee the violence).

Additionally, the international food price crisis may have affected farmers' decisions with regard to marketing and spending in all three countries.

This section describes results, organized according to the two research objectives.

\section{Participation in Farmer Field Schools}

Do the poor and other marginalized groups participate in farmer field schools? Do such schools tend to be unavailable to or discriminate against women or men, the old or young, or the rich or poor? We examined participation issues through survey data and key informant interviews.

According to key informants in Tanzania, the collection of farmers involved in FFSs is mixed, and the very poor $d o$ participate. Wealthier farmers tend not to engage in FFSs because they do not want to waste time on activities such as the key FFS activity, the agro-ecosystem analysis (splitting into groups and noting with pictures what is going on in the fields)The schools intentionally encourage different age groups to participate as well.

During the study inception workshop, participants were asked whether the poor and marginalized participated in FFSs. Respondents stated that poor people did participate, and that most of the participants were from the low- or middle-income groups. The criteria for selection and the process of participant identification (sensitization, registration, and training) enable the poor and other marginalized groups to participate. On the other hand, there are some basic requirements to join the groups (such as a small fee), and thus "poor people [may] shy away." Sometimes the very poor are farm laborers working on other people's farms and thus cannot participate. The poor especially do not participate in leadership of FFSs.

According to respondents at the inception workshop, a couple of problems might occur when FFS programs target poorer households. One is that there may be a "race to the bottom," where people may pose as poor to get benefits and are not actually interested in the program for any other reason. The second problem is that extension agents and other government personnel have performance contracts, and so are under pressure to work where they will see the most results (not necessarily among the poor).

With regard to the household survey results, Table 2 shows that FFS members in Kenya were about 66 percent female, while Tanzanian female members accounted for 31 percent and Ugandan female FFS members 50 percent. In Kenya and Uganda, about 60 percent of FFS members had only primary education; in Tanzania 80 percent had only primary education. Tanzanian FFS members also had the lowest level of tertiary education ( 0.7 percent). 
Table 2. Participation in FFSs across gender and level of education (based on individual membership)

\begin{tabular}{lcccccc}
\hline Country & $\begin{array}{c}\text { Male } \\
\mathbf{( \% )}\end{array}$ & $\begin{array}{c}\text { Female } \\
\mathbf{( \% )}\end{array}$ & $\begin{array}{c}\text { No } \\
\text { education } \\
(\mathbf{\%})\end{array}$ & $\begin{array}{c}\text { Primary } \\
\text { education } \\
\mathbf{( \% )}\end{array}$ & $\begin{array}{c}\text { Secondary } \\
\text { education } \\
\mathbf{( \% )}\end{array}$ & $\begin{array}{c}\text { Tertiary } \\
\text { education** } \\
\mathbf{( \% )}\end{array}$ \\
\hline Kenya $(n=300)$ & 33.7 & 66.3 & 8.7 & 60.7 & 27.0 & 6.0 \\
Tanzania $(n=284)$ & 68.7 & 31.3 & 9.2 & 80.3 & 10.9 & 0.7 \\
Uganda $(n=267 *)$ & 49.8 & 50.2 & 13.5 & 57.5 & 26.7 & 5.3 \\
All $(n=851)^{*}$ & 50.4 & 49.6 & 10.4 & 66.2 & 21.5 & 4.0 \\
\hline
\end{tabular}

Notes: $*$ For education, $n=850$ for all and $n=266$ for Uganda.

** College, university.

\section{Determinants of Participation in FFS}

We examined determinants of FFS participation using a probit regression model. Gender of household head did not have a significant impact on participation in Kenya and Tanzania and for all countries combined (Table 3). This demonstrates that FFS participation was equally available to both male and female community members in the two countries. In Uganda, however, female-headed households were less likely to participate in the field schools.

Households whose head had primary or secondary education were more likely to participate in FFSs in Kenya than those with no formal education. In Uganda, however, households whose head had primary or secondary education were less likely to participate than households whose head had no formal education. In Tanzania and in all three countries combined, level of education had no impact on participation in FFSs. This could be because in Tanzania a large share of farmers have only primary education and a much smaller share have postprimary education (Table 3 ).

We used bootstrapping to compute the standard errors of the estimated ATT, generating robust standard errors because the matching procedure matched control households to treatment households "with replacement" (see Abadie and Imbens 2002).

Combining matching methods and ATT controls bias due to differences in pre-FFS observable characteristics. A bias could still result from the time-variant variables or the unobservable differences between participants and nonparticipants. Hence we also used qualitative methods to assess the impact of the field schools. A combination of methods helps to address the shortcomings of impact assessment methods (Duflo, Glennerster, and Kremer 2006).

Primary education of the spouse of the household head for all countries combined, Uganda, and Tanzania negatively affected participation in FFSs. The results demonstrate that field schools in East Africa were more accessible to households with less-educated household head spouses, the majority of whom were female. As we show later, FFSs had a significant impact on agricultural income of femaleheaded households. Membership in savings and credit groups and farmer groups other than FFSs also significantly increased the propensity to participate in FFSs for all countries combined and in each country. ${ }^{3}$ This demonstrates the effectiveness of farmer groups in enhancing access to rural services. As expected, having nonfarm activities reduced the probability of participating in FFSs in Kenya, but it had no impact in Tanzania and Uganda and for all countries combined. The opportunity cost faced by farmers who engage in nonfarm activities may be higher, and therefore such farmers may not be able to participate in FFS activities and may not be able to adopt technologies promoted by the field schools.

In each country, younger farmers were more likely to participate in FFSs than older farmers. This shows the potential of the schools to promote new agricultural technologies to younger farmers. Also,

\footnotetext{
${ }^{3}$ But the impact of membership in non-FFS farmer groups in Uganda was not significant at 10 percent.
} 
those farmers who were members of savings and credit groups or other farmer groups were more likely to participate than those who were not members.

Table 3. Determinants of participation in FFSs (probit regressions with village fixed effects)

\begin{tabular}{|c|c|c|c|c|}
\hline Variable & $\begin{array}{l}\text { All countries } \\
\text { pooled }\end{array}$ & Kenya & Tanzania & Uganda \\
\hline Female household head & 0.078 & -0.143 & 0.25 & $-3.470^{* * *}$ \\
\hline \multicolumn{5}{|l|}{$\begin{array}{l}\text { Household head education level (cf. no formal } \\
\text { education) }\end{array}$} \\
\hline Primary education & 0.333 & $0.715^{*}$ & 0.327 & $-5.000 * *$ \\
\hline Secondary education & 0.273 & $0.989 * *$ & 0.057 & $-8.463 * *$ \\
\hline Tertiary education & 0.276 & 1.154 & -0.255 & -0.02 \\
\hline \multicolumn{5}{|c|}{ Spouse level of education (cf. no formal education) } \\
\hline Primary education & $-0.308^{*}$ & -0.278 & $-0.949 * *$ & $-4.436 * * *$ \\
\hline Secondary education & 0.293 & 0.071 & -0.31 & 5.193 \\
\hline Tertiary education & -0.828 & $-1.374 *$ & & -1.752 \\
\hline Member of savings and credit group & $0.695 * * *$ & $0.794 * *$ & $0.696 * * *$ & $2.484 * *$ \\
\hline Member of farmer group other than FFS & $0.985 * * *$ & $14.123 * * *$ & $1.346^{* *}$ & 2.493 \\
\hline Household earns off-farm income & -0.057 & $-0.779^{*}$ & 0.407 & 0.73 \\
\hline Log (age of household head) & -0.305 & $-0.936 * *$ & $-0.827 * *$ & $-7.890 * *$ \\
\hline Log (household size) & -0.073 & $-1.276 * * *$ & 0.243 & 1.222 \\
\hline Dependency ratio & 0.317 & $1.786^{* * *}$ & -0.033 & $-17.851 * * *$ \\
\hline Log (distance to tarmac road, $\mathrm{km}$ ) & $-0.169 * *$ & $-1.166^{* * *}$ & -0.054 & $2.735^{*}$ \\
\hline Log (distance to market/town, $\mathrm{km}$ ) & $0.237 * * *$ & $0.905 * * *$ & $0.272 * *$ & $-5.006^{* * *}$ \\
\hline Log (land, acres) & 0.013 & 0.095 & -0.026 & $4.033 * *$ \\
\hline Constant & 0.828 & -3.195 & $3.067 *$ & 15.89 \\
\hline Joint significance of fixed effects ( $p$-value) & $0.000 * * *$ & $0.000 * * *$ & $0.000 * * *$ & $0.000^{* * *}$ \\
\hline Number of observations & 1,125 & 397 & 379 & 349 \\
\hline
\end{tabular}

Notes: *,*, and $* * *$ indicate significance at the $0.10,0.05$, and 0.01 levels, respectively. Standard errors robust to heteroskedasticity.

Household size was also negatively related to the probability to participate in an FFS in Kenya, but it had no impact in Tanzania and Uganda. The dependency ratio, which is the ratio of the number of dependents divided by the number of working adults, was positively related with the probability to participate in an FFS in Kenya, but it was negatively associated with participation in Uganda and had a nonsignificant impact in Tanzania and all countries combined. Given that households with a higher dependency ratio were more likely to be poor than those with a lower dependency ratio, the results reveal the potential that FFSs have for reducing poverty in Kenya. However, the dependency ratio generally showed no significant impact on the probability of participation in an FFS.

Distance to tarmac roads was negatively related with the propensity to participate in an FFS in Kenya and for all countries combined, suggesting that farmers in remote areas are less likely to take part in the schools. In Uganda, however, distance to tarmac roads increased the propensity to participate in FFS. In Tanzania, distance to tarmac roads had no significant impact on the likelihood of participation. These results could be due to the different placement of the FFSs in the three countries, as well as the countries' relative infrastructure. 
Controlling for access to tarmac roads, education, and other factors, distance to nearest market/urban area was positively related with the likelihood to participate in an FFS in all countries combined and for Kenya and Tanzania. The results are contrary to those of distance to tarmac road and suggest distance to urban areas was positively associated with propensity to participate in FFS. In Uganda, the contrary is the case - that is, farmers closer to urban areas were more likely to participate in an FFS than those in a remote area. But it was also in Uganda that distance to tarmac roads increased the propensity to participate in an FFS, which is contrary to expectations.

Area (size) of the farm did not have a significant impact on the probability to participate in an FFS in Kenya and Tanzania and for all countries combined, but it was positively related to FFS participation in Uganda.

In summary, membership in savings and credit groups and non-FFS farmer groups, proximity to tarmac roads, and low education of spouses increased the propensity to participate in an FFS. The results also show that younger farmers are more likely to participate than older farmers. Other covariates showed inconsistent impacts across countries, and some did not have significant impact.

An important aspect to consider in demand-driven programs such as the FFS program is the reasons that farmers give for not participating in the program. Table 4 shows the main reasons respondents gave for not participating in an FFS. The major reasons include lack of time, distance from the venue, and lack of information. Tanzania had a relatively high number of respondents who stated that the venue was too far away (27.1 percent). However, 40.2 percent of Tanzanian nonparticipants stated that they would "join soon." A good number of Kenyan respondents claimed they did not have enough time to join the FFS (64.8 percent), and a good number of Ugandans said they lacked information (53.2 percent.

\section{Table 4. Reasons for not joining an FFS (\%)}

\begin{tabular}{lcccc}
\hline & $\begin{array}{c}\text { Kenya } \\
(\boldsymbol{n}=\mathbf{8 8})\end{array}$ & $\begin{array}{c}\text { Uganda } \\
(\boldsymbol{n}=\mathbf{4 7})\end{array}$ & $\begin{array}{c}\text { Tanzania } \\
(\boldsymbol{n}=\mathbf{1 0 7})\end{array}$ & $\begin{array}{c}\text { All }(\boldsymbol{n}= \\
\mathbf{2 4 2})\end{array}$ \\
Reasons & & & & 32.6 \\
\hline 1 Lack of time; commitments & 64.8 & 21.3 & - & 4.1 \\
2 Leadership not good enough & 5.7 & 10.6 & 40.2 & 21.1 \\
3 To join soon & 3.4 & 10.6 & 27.1 & 15.7 \\
4 The venue is far from my home & 8.0 & 4.3 & - & 15.7 \\
5 Lack of information on & 14.8 & 53.2 & - & 1.2 \\
$\quad$ enrollment & 3.4 & 0 & 4.7 & 2.1 \\
6 Lack of capital & - & - & 15.0 & 6.7 \\
7 To join after observing results & - & - & 1.9 & 0.8 \\
8 No FFS around & - & - & \\
9 Too old & & &
\end{tabular}

This section examined participation in FFSs, noting that women appeared to be able to participate freely. Additionally, younger farmers, farmers who were members of other groups, and farmers close to tarmac roads were more likely to participate. The next section examines the impacts of FFSs on various outcomes.

\section{Impacts of Farmer Field Schools on Various Outcomes}

In this section we report results with regard to the effect of FFSs on outcomes such as poverty, gender, and productivity, and. As mentioned in Section 3, we conducted balancing tests. For Kenya, the balancing test shows that only spouse primary education is not balanced (Appendix Table A.1). In Tanzania, 
secondary education of household head and primary education of his or her spouse are not balanced (Appendix Table A.2). In Uganda, primary education of household head and distance to tarmac road are not balanced (Appendix Table A.3). These tests suggest a bias will persist and suggest the need to compare the results obtained from PSM with those obtained from covariate matching. In the discussion, we mainly use covariate matching, which is robust to the bias observed in the data.

In assessing the impacts of the schools, we limited ourselves to only the partial equilibrium effects (first-order effects) and did not examine the general equilibrium effects of FFSs, which would require the more extensive computable general equilibrium modeling and multimarket models for which we do not have detailed data. This section examines only the effects of FFSs on crop productivity, livestock production, and agricultural income using the analytical methods explained earlier. It does so across country level, gender of household head, land size terciles, and education level of household head.

\section{Impact on Crop Productivity}

Crop productivity is defined as the value of production per unit area. Crop productivity is examined in the different countries, across gender, across land terciles, and across education. The value of crop production before and after farmer field schooling is shown in Appendix B.

\section{Impact on Crop Productivity across Countries}

Tables 5, 6, and 7 and Figure 3 show the impact of FFSs on crop productivity across countries, gender, and level of education of household head and poverty groups defined across land area. Overall, farmer field schooling had a significant impact on crop productivity in Kenya and Tanzania. As summarized in Figure 3, the FFS participation had a significantly larger impact on crop productivity in Kenya than in Tanzania and Uganda. The value of crop productivity per acre for farmers participating in an FFS increased by about 80 percent in Kenya, an increase that demonstrates the schools' effectiveness in increasing productivity. In Tanzania, the value of crop productivity for FFS members increased by 23 percent. The results are consistent with several other studies showing positive effects of FFSs on productivity (Gockowski et al. 2006; Godtland et al. 2004; Ortiz et al. 2004; Yamazaki and Resosudarmo 2006).

However, the results are contrary to those of Feder, Murgai, and Quizon (2004a), who found that FFSs had no significant impact on crop yield in Indonesia. Consistent with Feder, Murgai, and Quizon's findings, however, FFSs did not have a significant impact on crop productivity in Uganda (Figure 3). The FFSs' nonsignificant impact in Uganda may be due to the presence of the National Agricultural Advisory Services (NAADS) program, which was running concurrently in the districts where FFSs were operating. For example, Soroti and Kabermaido districts were among the NAADS trailblazing districts, and NAADS started operating in Busia in 2003. ${ }^{4}$ The presence of a well-advanced demand-driven program in Uganda could have contributed to the weak impact of FFSs. As will be seen later, however, FFSs had the largest impact on crop productivity for female participants in Uganda.

The adjacent tables show the impact of farmer field schooling on crop productivity in Kenya (Table 5), Tanzania (Table 6), Uganda (Table 7), and on all three countries combined (East Africa- Table 8 ), as well as the regional-/project-level effects (Table 8). The tables use PSM estimators and covariate matching with ATT to provide more rigorous evidence of the differences between FFS and non-FFS members, and according to gender, land size, and education level of household head.

\footnotetext{
${ }^{4}$ Kabermaido was part of Soroti District before it became a new district in 2001.
} 
Figure 3. Impact of FFS participation on value of crops produced per acre

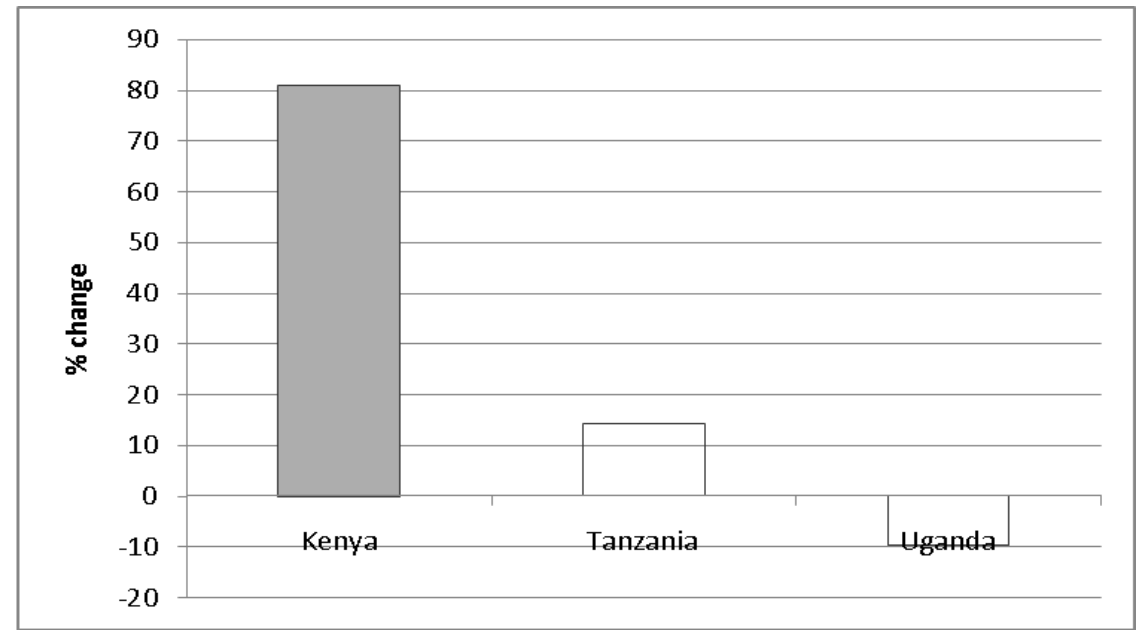

Notes: Bars without fill indicate impact not significant at $10 \%$ level.

For details showing the mean and median levels of value of crop production before and after farmer field schooling as well as the ATT estimates, see Appendix Tables B.1 through B.7.

Table 5. Impact of FFS participation on value of crop productivity in Kenya (Kenyan shillings)

\begin{tabular}{|c|c|c|c|c|}
\hline & \multicolumn{2}{|c|}{$\begin{array}{c}\text { Propensity score } \\
\text { matching estimators }\end{array}$} & \multirow{2}{*}{$\begin{array}{c}\text { Non-propensity score } \\
\text { matching estimator } \\
\text { Covariate matching } \\
\text { ATT }\end{array}$} & \multirow[b]{2}{*}{$\%$ change } \\
\hline & $\begin{array}{c}\text { Kernel } \\
\text { matching } \\
\text { ATT }\end{array}$ & $\begin{array}{c}\text { Nearest-neighbor } \\
\text { matching } \\
\text { ATT }\end{array}$ & & \\
\hline $\begin{array}{l}\text { FFS members versus non-FFS } \\
\text { members }\end{array}$ & $5,733 * * *$ & $5,650 * * *$ & $5,860 * * *$ & $81.0 \% * * *$ \\
\hline $\begin{array}{l}\text { FFS female-headed hhds }{ }^{\mathrm{a}} \text { versus } \\
\text { non-FFS female- headed hhds }\end{array}$ & $-5,830$ & $-3,770$ & 7,040 & $83.2 \%$ \\
\hline $\begin{array}{l}\text { FFS male-headed hhds versus non- } \\
\text { FFS male-headed hhds }\end{array}$ & $4,821 * *$ & 4,544 & $4,641 *$ & $34.3 \% *$ \\
\hline \multicolumn{5}{|l|}{$\begin{array}{l}\text { Impact across land poverty } \\
\text { terciles }\end{array}$} \\
\hline Land-poor & -539 & -537 & $-4,844$ & $-63.1 \%$ \\
\hline Land-middle & $7,722 *$ & $8,449 * * *$ & $15,205 * * *$ & $244.8 \% * * *$ \\
\hline Land-rich & 3,976 & 3,971 & 1,449 & $18.2 \%$ \\
\hline
\end{tabular}

Notes: ${ }^{\text {a }}$ hhds $=$ households.

$*, * *$, and $* * *$ indicate significance at the $0.10,0.05$, and 0.01 levels, respectively. 
Table 6. Impact of FFS participation on value of crop productivity in Tanzania (Tanzanian shillings)

\begin{tabular}{|c|c|c|c|c|}
\hline & \multicolumn{2}{|c|}{$\begin{array}{c}\text { Propensity score } \\
\text { matching estimators }\end{array}$} & \multirow{2}{*}{$\begin{array}{c}\text { Non-propensity score } \\
\text { matching estimator }\end{array}$} & \multirow[b]{2}{*}{$\begin{array}{c}\% \\
\text { change }\end{array}$} \\
\hline & $\begin{array}{c}\text { Kernel } \\
\text { matching } \\
\text { ATT }\end{array}$ & $\begin{array}{c}\text { Nearest- neighbor } \\
\text { matching } \\
\text { ATT } \\
\end{array}$ & & \\
\hline $\begin{array}{l}\text { FFS members versus non-FFS } \\
\text { members }\end{array}$ & 16,131 & 16,131 & $25,902 * *$ & $22.8 \%$ ** \\
\hline Female-headed & 31,227 & 31,227 & $88,714 * * *$ & $55.3 \% * * *$ \\
\hline Male-headed & 15,982 & 15,982 & $24,724 * *$ & $23.3 \% * *$ \\
\hline \multicolumn{5}{|c|}{ Impact across land poverty terciles } \\
\hline Land-poor & $-22,796$ & $-27,796$ & $-16,619$ & $-12.4 \%$ \\
\hline Land-middle & $51,309^{* * *}$ & $51,309 * * *$ & $58,879 * * *$ & $48.0 \% * * *$ \\
\hline Land-rich & 31,954 & 31,954 & 14,289 & $26.3 \%$ \\
\hline \multicolumn{5}{|c|}{$\begin{array}{l}\text { Impact across education levels of } \\
\text { household heads (FFS vs. non-FFS } \\
\text { of the same education level })^{a}\end{array}$} \\
\hline Education-none & $87,461^{*}$ & 87,461 & $81,903 * * *$ & $129.9 \% * * *$ \\
\hline Education-primary & 23,158 & $23,158 *$ & 16,001 & $14.6 \%$ \\
\hline Education-secondary & 50,833 & 50,833 & 19,059 & $10.6 \%$ \\
\hline
\end{tabular}

Notes: ${ }^{\mathrm{a}}$ The tertiary education group is not included due to a small sample, which led to nonconvergence of estimates.

$*, * *$, and $* * *$ indicate significance at the $0.10,0.05$, and 0.01 levels, respectively.

Table 7. Impact of FFS participation on crop productivity in Uganda (Ugandan shillings)

\begin{tabular}{|c|c|c|c|c|}
\hline \multirow[b]{2}{*}{$\begin{array}{l}\text { Value of crop production } \\
\text { (Uganda shillings/acre) }\end{array}$} & \multicolumn{2}{|c|}{$\begin{array}{l}\text { Propensity score } \\
\text { matching estimators }\end{array}$} & \multirow{2}{*}{$\begin{array}{c}\text { Covariate } \\
\text { matching } \\
\text { ATT } \\
\end{array}$} & \multirow[t]{2}{*}{$\%$ change } \\
\hline & $\begin{array}{l}\text { Kernel } \\
\text { matching } \\
\text { ATT }\end{array}$ & $\begin{array}{c}\text { Nearest-neighbor } \\
\text { matching } \\
\text { ATT }\end{array}$ & & \\
\hline $\begin{array}{l}\text { FFS members versus non-FFS } \\
\text { members }\end{array}$ & $-26,567$ & $-34,898$ & $-19,610$ & $-9.7 \%$ \\
\hline $\begin{array}{l}\text { FFS female-headed hhds }{ }^{\text {a }} \text { versus non- } \\
\text { FFS female-headed hhds }\end{array}$ & 141,579 & 165,171 & $120,773^{*}$ & $101.8 \%$ \\
\hline $\begin{array}{l}\text { FFS male-headed hhds versus non- } \\
\text { FFS male-headed hhds }\end{array}$ & $-91,952$ & $-121,829^{*}$ & $-90,330 *$ & $-41.6 \%$ \\
\hline \multicolumn{5}{|l|}{ Impact across land poverty terciles } \\
\hline Land-poor & $-187,771$ & $-218,856^{* *}$ & $-89,278$ & $-55.6 \%$ \\
\hline Land-middle & 109,974 & $135,131^{*}$ & $217,376^{* * *}$ & $104.6 \% * * *$ \\
\hline Land-rich & $-103,108$ & $-108,152$ & $-153,213$ & $-66.0 \%$ \\
\hline
\end{tabular}

Notes: ${ }^{\mathrm{a}}$ hhds $=$ households.

$*, * *$, and $* * *$ indicate significance at the $0.10,0.05$, and 0.01 levels, respectively. 
Table 8. Impact of FFS participation on value of crop productivity per acre in East Africa (U.S. dollars)

\begin{tabular}{|c|c|c|c|c|}
\hline & \multicolumn{2}{|c|}{$\begin{array}{l}\text { Propensity score } \\
\text { matching estimators } \\
\text { ATT (US\$) }\end{array}$} & \multirow[t]{2}{*}{$\begin{array}{c}\text { Covariate } \\
\text { matching } \\
\text { ATT (US\$) } \\
\end{array}$} & \multirow[t]{2}{*}{$\begin{array}{l}\text { \% change } \\
\text { (covariate } \\
\text { matching) }\end{array}$} \\
\hline & $\begin{array}{l}\text { Kernel } \\
\text { matching }\end{array}$ & $\begin{array}{l}\text { Nearest- neighbor } \\
\text { matching }\end{array}$ & & \\
\hline $\begin{array}{l}\text { FFS members versus non-FFS } \\
\text { members }\end{array}$ & -0.07 & -0.41 & $29.9 * *$ & $32 \% * * *$ \\
\hline \multicolumn{5}{|c|}{$\begin{array}{l}\text { Impact across household headship } \\
\text { (FFS vs. non-FFS of the same } \\
\text { gender) }\end{array}$} \\
\hline Female-headed households & 51.0 & $61.5^{*}$ & $117.8 * * *$ & $139 \% * * *$ \\
\hline Male-headed households & -25.5 & -15.3 & 14.3 & $15 \%$ \\
\hline \multicolumn{5}{|c|}{ Impact across land poverty terciles } \\
\hline Land-poor & -47.5 & -30.5 & -43.2 & $-44 \%$ \\
\hline Land-middle & $92.8^{* * *}$ & $93.4 * * *$ & $94.5^{* * *}$ & $105 \% * * *$ \\
\hline Land-rich & -11.8 & -33.1 & -8.5 & $-9 \%$ \\
\hline \multicolumn{5}{|c|}{$\begin{array}{l}\text { Impact across education levels of } \\
\text { household heads (FFS vs. non-FFS } \\
\text { of the same education level })^{a}\end{array}$} \\
\hline No formal education & $132.9^{* *}$ & $123.9 * *$ & $173.4 * * *$ & $254 \% * * *$ \\
\hline Primary education & 3.8 & 3.4 & 19.4 & $21 \%$ \\
\hline Secondary education & 32.6 & 28.9 & 34.9 & $30 \%$ \\
\hline
\end{tabular}

Notes: ${ }^{\text {a }}$ The tertiary education group is not included due to a small sample, which led to nonconvergence of estimates.

$*, * *$, and $* * *$ indicate significance at the $0.10,0.05$, and 0.01 levels, respectively.

\section{Impact on Crop Productivity across Gender of Household Head}

As expected, the impact of farmer field schooling differed significantly across gender of household head. FFS participation meant a significant increase in crop productivity for female-headed households in Tanzania, Uganda, and all three countries combined (Figure 4). The increase in crop productivity among females was greater than males for both the absolute value (ATT) and the percentage increase. Although Kenya had the highest number of women participants (66 percent), there was no significant difference in crop productivity between female- and male-headed FFS participants in Kenya.

The participation by women and the significant benefits gained through their participation in many cases is contrary to findings of other studies that have reported limited access to extension services by women farmers compared with men (FAO 1997; Haug 1999). The results demonstrate that FFSs are accessible to women farmers, who contribute the most in agricultural production in Sub-Saharan Africa. FFSs' impact on crop productivity among male participants was positive and significant in Kenya (at the 10 percent level) and Tanzania (at the 5 percent level) but was nonsignificant for all countries combined. Crop productivity of male FFS participants actually declined in Uganda as it did throughout the country during this period (Benin et al. 2007). The results suggest that farmer field schooling was more beneficial to women than to men. 
Figure 4. Impact of FFS participation on crop productivity across gender of household head (\% change in value of crop production/acre)

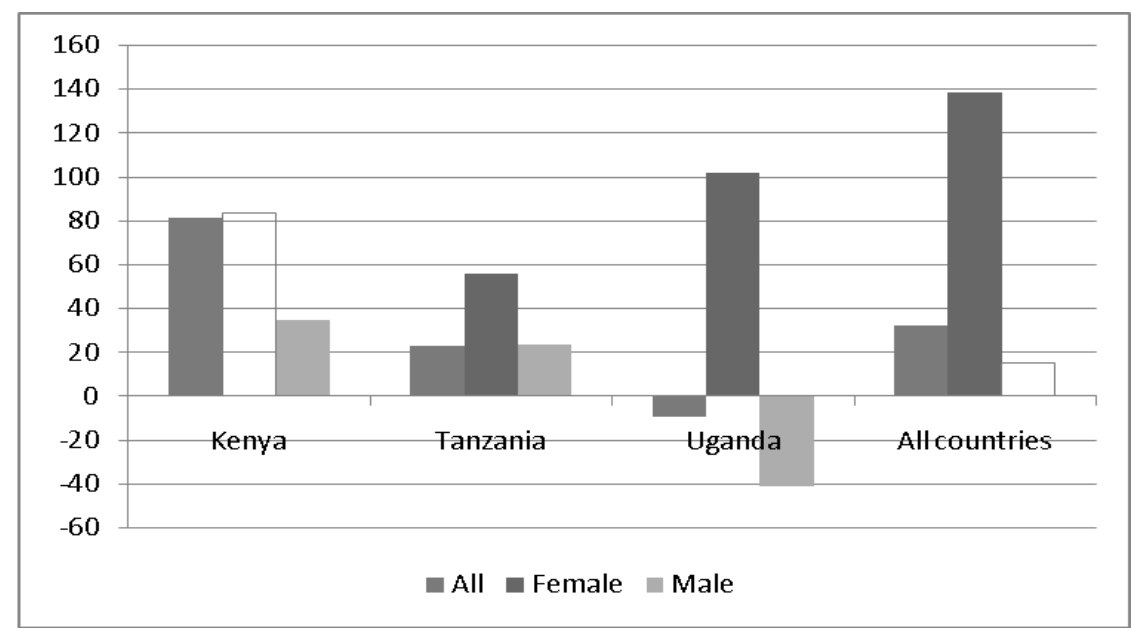

Notes: Bars without fill indicate impact not significant at the $10 \%$ level.

For details showing the mean and median levels of value of crop production, livestock income, and total agricultural income before and after FFS participation as well as the ATT estimates, see Appendix Tables B.1 through B.7.

\section{Impact on Crop Productivity across Land Poverty Terciles}

Figure 5 shows that FFS participants farming medium-size land areas benefited the most across all three countries. Additionally, the impact of FFSs on crop productivity for land-poor participants was negative but nonsignificant. The results suggest that although the field schools were accessible and beneficial to women participants, their impact on farmers with small land areas - who are likely to be poor - was weak. Farmers working small land areas could be resource poor-hence with limited capacity to invest in technologies promoted by the FFSs. Interestingly, however, the impact of farmer field schooling on crop productivity for participants farming relatively larger land areas was not significant in Kenya, Uganda, and in the three countries pooled.

Overall, the results suggest that farmers with smaller land areas did not benefit significantly from FFS participation - an observation that contradicts what was observed for the gender analysis, where we found that women FFS participants benefited more than men.

Figure 5. Impact of FFS participation on crop productivity across land poverty terciles

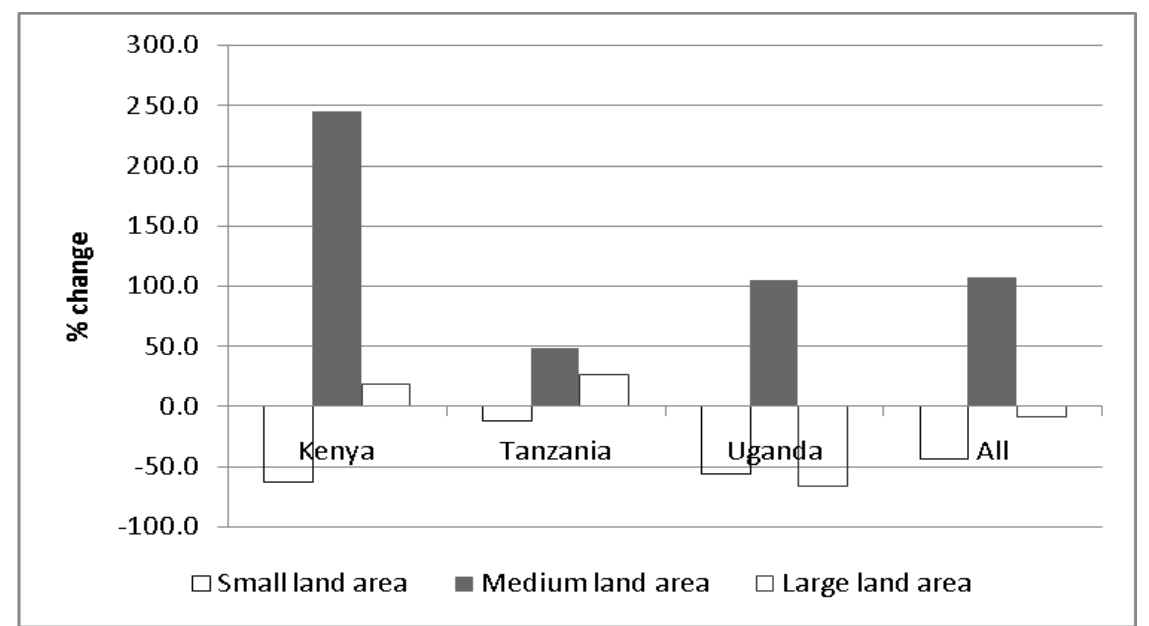

Note: Bars without fill indicate impact not significant at the $10 \%$ level. 


\section{Impact on Crop Productivity across Level of Education of Household Head}

Participation in an FFS increased the crop productivity of farmers with no formal education across all countries and for all countries combined. The increase in crop productivity for participants with no formal education was greater than for any other group of farmers with higher levels of education both in terms of percentage and in absolute value of the increase (Figure 6). This suggests that the approach is accessible and beneficial to participants with little or no formal schooling. It is an interesting finding given that FFSs have been criticized for potentially keeping out low-literacy farmers. It shows that the experiential learning and demonstration focus of the FFSs appears to allow low-literacy farmers to actively participate and learn.

\section{Impact on Livestock Production}

A greater share of FFS participants adopted livestock breeds and management technologies than of nonFFS households. Likewise, a greater share of FFS farmers demanded livestock breeds and livestock management technologies than of non-FFS households. In the following subsections, we examine whether adoption of and demand for livestock technologies had an impact on productivity. Figures 7 through 9 show the impacts of farmer field schooling on livestock income, which is measured as value of livestock production per household.

Generally across the project, FFS participation did not have a significant impact on livestock production per household. Additionally, the increase in livestock production due to FFS participation was smaller (14 percent) than the case of crop productivity (32 percent). However, the impact of FFSs on livestock production was greater in Kenya and Uganda than in Tanzania. This could be due to the emphasis on crop production by extension services and farmers' demand. Livestock's contribution to household income and the gross domestic product is low in general for all three countries. As will be seen later, however, the FFSs' impact on livestock production among women participants was significant in all countries combined and in Kenya and Tanzania.

Figure 6. Impact of FFS participation on crop productivity across education levels of household head

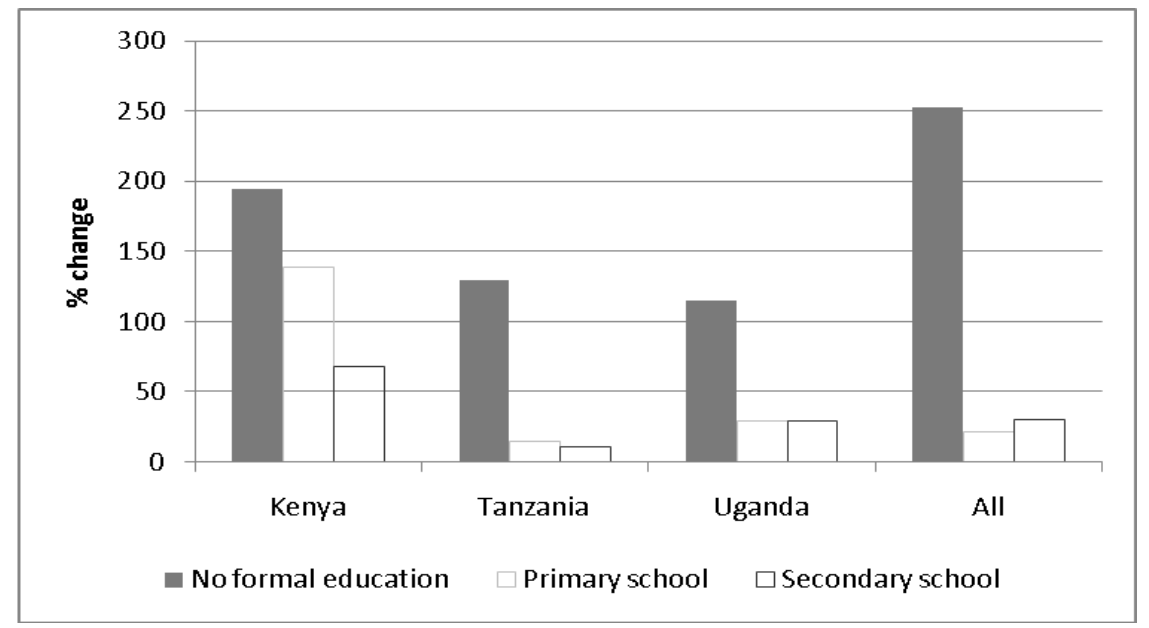

Notes: Bars without fill indicate impact not significant at the $10 \%$ level.

For details showing the mean and median levels of value of crop production, livestock income, and total agricultural income before and after FFS participation as well as the ATT estimates, see Appendix Tables B.1 through B.7. 


\section{Impact on Livestock Production across Gender}

Comparison of livestock production across gender shows that women participants benefited more than men from livestock technologies. Tables 9 through 12 and Figure 7 show that livestock production of female FFS participants in all countries combined increased 23 percent, and by 159 percent and 187 percent in Kenya and Uganda, respectively. However, livestock production in Tanzania for female and male participants did not change significantly. The results generally show that livestock technologies are more beneficial to female FFS participants than to men, even in Uganda where FFSs had a limited impact. Livestock production has generally been a male activity, and women have been engaged in production of small ruminants and chickens (Curry 1996; Thornton et al. 2002). However, the adoption of improved livestock breeds among women farmers in East Africa has been increasing and could explain this significant impact.

The adjacent tables show the impact of FFS participation on livestock income in Kenya (Table 9), Tanzania (Table 10), and Uganda (Table 11), and on all three countries combined (Table 12). The tables use PSM estimators and covariate matching with ATT to provide more rigorous evidence of the differences between FFS and non-FFS members, and according to gender, land size, and education level of household head.

Figure 7. Impact of FFS participation on livestock production across gender of household head (\% change in value of livestock per household)

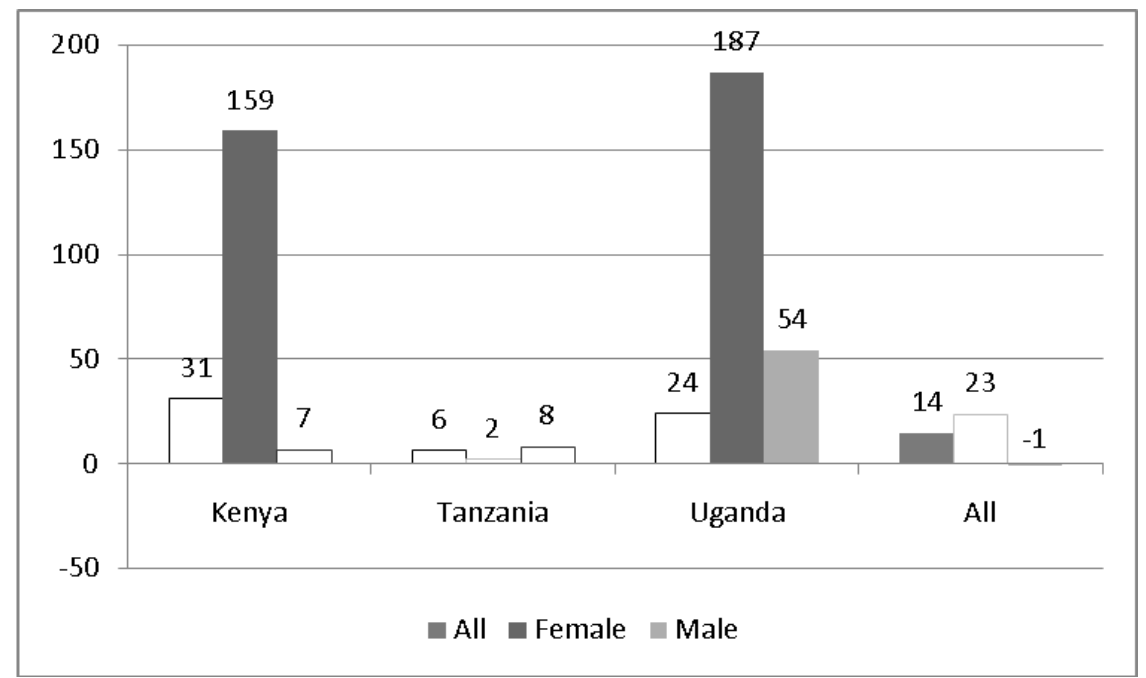

Notes: Bars without fill indicate impact not significant at the $10 \%$ level.

For details showing the mean and median levels of value of crop production, livestock income, and total agricultural income before and after FFS participation as well as the ATT estimates, see Appendix Tables B.1 through B.7. 
Table 9. Impact of FFS participation on livestock income in Kenya (Kenyan shillings)

\begin{tabular}{|c|c|c|c|c|}
\hline & \multicolumn{2}{|c|}{$\begin{array}{c}\text { Propensity score } \\
\text { matching estimators }\end{array}$} & \multirow{2}{*}{$\begin{array}{c}\text { Non-propensity score } \\
\text { matching estimator } \\
\text { Covariate matching } \\
\text { ATT }\end{array}$} & \multirow[b]{2}{*}{$\%$ change } \\
\hline & $\begin{array}{c}\text { Kernel } \\
\text { matching } \\
\text { ATT }\end{array}$ & $\begin{array}{c}\text { Nearest- neighbor } \\
\text { matching } \\
\text { ATT }\end{array}$ & & \\
\hline $\begin{array}{r}\text { FFS members versus non- } \\
\text { FFS members }\end{array}$ & 1,853 & 2,915 & 2,613 & $31 \%$ \\
\hline Female-headed households & 2,262 & 2,645 & $15,202 * * *$ & $158 \% * * *$ \\
\hline Male-headed households & 339 & 1,242 & 550 & $7 \%$ \\
\hline Land-poor & $-1,557$ & 52 & 1,858 & $19 \%$ \\
\hline Land-middle & 2,546 & 2,088 & $4,508 * *$ & $69 \% * *$ \\
\hline Land-rich & $-1,893$ & $-3,625$ & $7,476 * *$ & $84 \% * *$ \\
\hline Education-none & 13,974 & 7,852 & $16,350 *$ & $207 \% *$ \\
\hline Education-primary & -194 & $-1,209$ & -844 & $-11 \%$ \\
\hline Education-secondary & 4,729 & 4,076 & $-6,063 *$ & $-66 \%$ \\
\hline
\end{tabular}

Note: $* * *$, and $* * *$ indicate significance at the $0.10,0.05$, and 0.01 levels, respectively.

Table 10. Impact of FFS participation on livestock income in Tanzania (Tanzanian shillings)

\begin{tabular}{|c|c|c|c|c|}
\hline & \multicolumn{2}{|c|}{$\begin{array}{c}\text { Propensity score } \\
\text { matching estimators }\end{array}$} & \multirow{2}{*}{$\begin{array}{c}\text { Non-propensity score } \\
\text { matching estimator } \\
\text { Covariate matching } \\
\text { ATT }\end{array}$} & \multirow[b]{2}{*}{$\%$ change } \\
\hline & $\begin{array}{c}\text { Kernel } \\
\text { matching } \\
\text { ATT }\end{array}$ & $\begin{array}{c}\text { Nearest-neighbor } \\
\text { matching } \\
\text { ATT }\end{array}$ & & \\
\hline $\begin{array}{l}\text { FFS members versus non- } \\
\text { FFS members }\end{array}$ & 10,354 & 14,806 & 8,556 & $6 \%$ \\
\hline Female-headed households & 1,564 & $-8,498$ & 2,476 & $2 \%$ \\
\hline Male-headed households & 8,864 & 5,294 & 10,610 & $8 \%$ \\
\hline Land-poor & $67,613^{*}$ & $69,355^{*}$ & 30,969 & $56 \%$ \\
\hline Land-middle & 150,615 & 110,667 & $87,484 * *$ & $61 \% * *$ \\
\hline Land-rich & 71,905 & $-23,974$ & $276,803 * * *$ & $218 \% * * *$ \\
\hline Education-none & 103,935 & $115,489 * *$ & $84,352 * * *$ & $137 \% * * *$ \\
\hline Education-primary & $-4,488$ & 2,734 & -204 & $-4 \%$ \\
\hline Education-secondary & $1,258,811$ & $1,037,002$ & $904,203 *$ & $248 \% *$ \\
\hline
\end{tabular}

Note: $* * *$, and $* * *$ indicate significance at the $0.10,0.05$, and 0.01 levels, respectively. 
Table 11. Impact of FFS participation on livestock income in Uganda (Ugandan shillings)

\begin{tabular}{|c|c|c|c|}
\hline & $\begin{array}{c}\text { Propensity score } \\
\text { matching estimators }\end{array}$ & $\begin{array}{l}\text { Non-propensity score } \\
\text { matching estimator }\end{array}$ & \\
\hline & Kernel matching & Covariate matching & $\%$ change \\
\hline $\begin{array}{l}\text { FFS members versus non-FFS } \\
\text { members }\end{array}$ & 12,144 & 87,610 & $26 \%$ \\
\hline Female-headed households & $-172,660$ & $343,557 * * *$ & $187 \% * * *$ \\
\hline Male-headed households & 160,765 & 215,945 & $60 \% * * *$ \\
\hline Land-poor & 292,518 & 278,431 & $78 \%$ \\
\hline Land-middle & 353,726 & $300,159 * * *$ & $82 \% * * *$ \\
\hline Land-rich & 102,545 & $-27,045$ & $-9 \%$ \\
\hline Education-none & $-94,250$ & $-2,755$ & $-2 \%$ \\
\hline Education-primary & $307,535^{* *}$ & $210,561 * *$ & $72 \% * *$ \\
\hline Education-secondary & $-2,703$ & $-88,535$ & $-22 \%$ \\
\hline
\end{tabular}

Note: $* * *$, and $* * *$ indicate significance at the $0.10,0.05$, and 0.01 levels, respectively.

Table 12. Impact of FFS participation on livestock income in all countries (U.S. dollars)

\begin{tabular}{|c|c|c|c|c|}
\hline & \multicolumn{2}{|c|}{$\begin{array}{c}\text { Propensity score } \\
\text { matching estimators }\end{array}$} & \multirow{2}{*}{$\begin{array}{c}\text { Covariate } \\
\text { matching } \\
\text { ATT (US\$) } \\
\end{array}$} & \multirow{2}{*}{$\begin{array}{l}\text { \% change } \\
\text { (covariate } \\
\text { matching) }\end{array}$} \\
\hline & $\begin{array}{c}\text { Kernel } \\
\text { matching } \\
\text { ATT (US\$) } \\
\end{array}$ & $\begin{array}{l}\text { Nearest- neighbor } \\
\text { matching } \\
\text { ATT (US\$) }\end{array}$ & & \\
\hline FFS versus non-FFS members & 35.7 & $45.3^{*}$ & $39.4^{*}$ & $14 \% *$ \\
\hline Female-headed households & 41.2 & 45.3 & 55.3 & $23 \% * *$ \\
\hline Male-headed households & 40.4 & -2.8 & -3.0 & $1 \%$ \\
\hline Land-poor & 37.7 & $51.6^{* *}$ & $85.6^{* * *}$ & $43.2 \% * * *$ \\
\hline Land-middle & 45.7 & $54.6 * *$ & $40.2 * * *$ & $21 \% * * *$ \\
\hline Land-rich & 23.9 & 18.9 & 21.0 & $5 \%$ \\
\hline \multicolumn{5}{|c|}{$\begin{array}{l}\text { Impact across education levels of } \\
\text { household heads (FFS vs. non-FFS of } \\
\text { the same education level) }\end{array}$} \\
\hline Education-none & 63.9 & $79.7 * *$ & $79.9 * * *$ & $42 \% * * *$ \\
\hline Education-primary & 36.3 & 22.4 & 17.7 & $8 \%$ \\
\hline Education-secondary & 122.7 & 66.7 & 66.8 & $19 \%$ \\
\hline
\end{tabular}

Notes: ${ }^{a}$ The tertiary education group is not included due to the small sample, which led to nonconvergence of estimates.

$*, * *$, and $* * *$ indicate significance at the $0.10,0.05$, and 0.01 levels, respectively. 


\section{Impact on Livestock Production across Land Poverty Terciles}

In each of the three countries, the livestock production of FFS participants farming a small land area increased, but the increase was not significant (Figure 8), suggesting the weak impact of FFSs on the land-poor smallholder farmers. At each country level and for all countries combined, FFS participation had a significant impact on livestock production for farmers with a medium-size farm. FFSs had a significant impact among FFS participants with a large land area in Kenya and Tanzania only. These results could be a result of livestock farmers in the East Africa region keeping unimproved livestock breeds and using a free-range feeding system, which requires a relatively large expanse of land. The results indicate that about 27 percent of the FFS farmers adopted improved breeds versus only 17 percent of non-FFS farmers. The majority of the adopters were likely livestock farmers who practiced grassland (free-range) systems that require a large land area.

Figure 8. Impact of FFS participation on livestock production across land poverty terciles

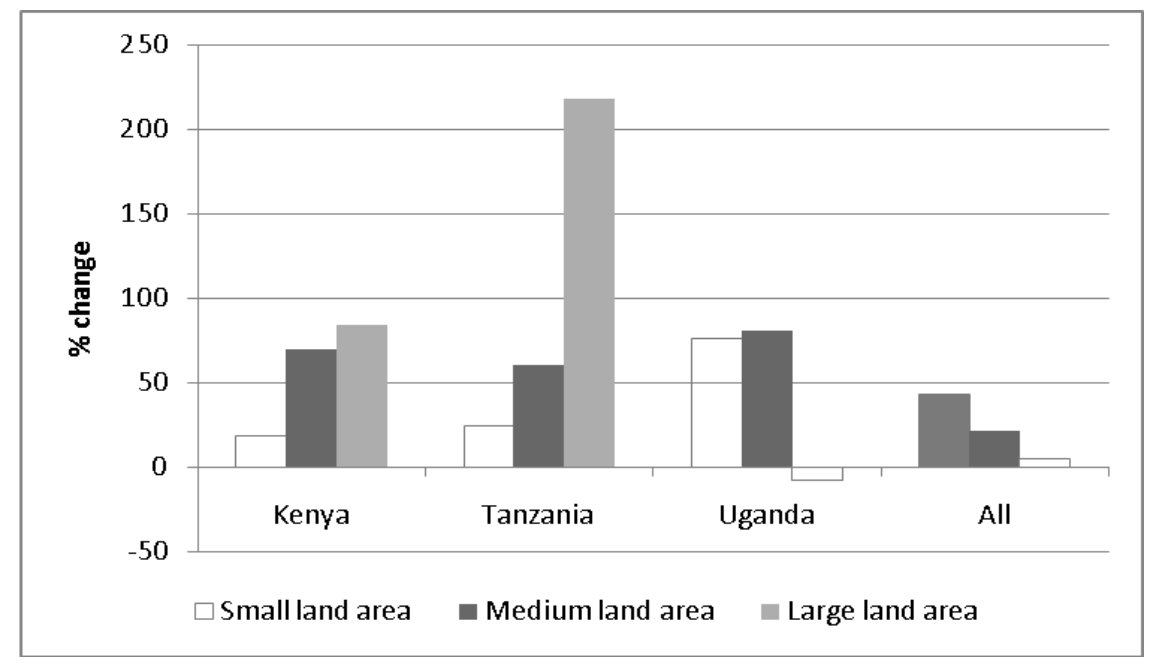

Notes: Bars without fill indicate impact not significant at the $10 \%$ level.

For details showing the mean and median levels of value of crop production, livestock income, and total agricultural income before and after FFS participation as well as the ATT estimates, see Appendix Tables B.1 through B.7.

\section{Impact on Livestock Production across Education Levels}

Comparison of the impact of farmer field schooling across level of education offers interesting results. Figure 9 shows that livestock production among FFS participants with no formal education in Kenya, Tanzania, and all countries combined increased significantly. These results are consistent with FFSs' impact on crop productivity, and further demonstrate that farmer field schooling benefited the poor and less-educated more than the better-educated participants. This is especially the case in Kenya and all countries combined, where both the percentage and absolute value (ATT) increase were greater for farmers with no formal education. In Tanzania, the percentage and absolute value (ATT) increase in livestock production for participants with secondary education were greater than the equivalent values for farmers with no formal education. In Uganda, livestock production increased significantly only for FFS participants with primary education. 
Figure 9. Impact of FFS participation on livestock production across education level of household head

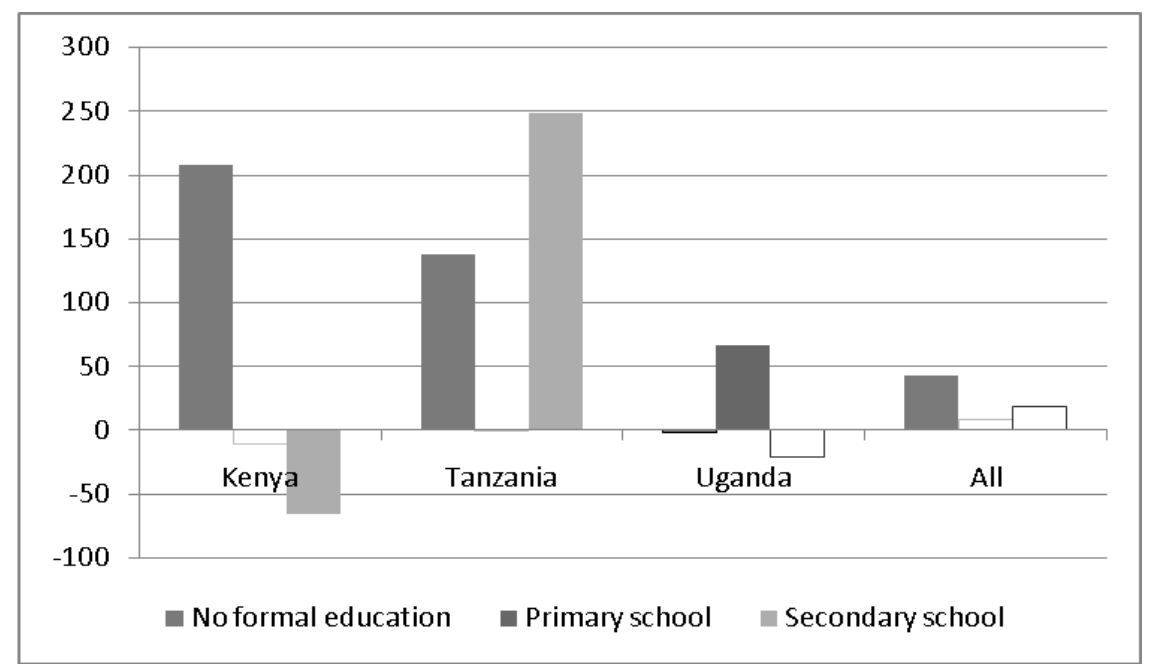

Notes: Bars without fill indicate impact not significant at the $10 \%$ level.

For details showing the mean and median levels of value of crop production, livestock income, and total agricultural income before and after FFS participation as well as the ATT estimates, see Appendix Tables B.1 through B.7

\section{Impact on Agricultural Income}

We used the value of crop production and the value of livestock produced to measure the impact of farmer field schooling on agricultural income (Figure 10). That impact, which is the sum of the value of crop production income and livestock income per household, differs across the three countries.

Comparison across countries shows that the FFSs had the largest impact on agricultural income in Tanzania, and the smallest (nonsignificant) impact in Uganda (Tables 13-16). Agricultural income of FFS members in Tanzania doubled due to participation in a field school (Figure 10). In Kenya, agricultural income increased by 21 percent. Consistent with the results in Tanzania and Uganda, crops contributed the largest share of the change. The agricultural income of FFS participants in Uganda increased by only 18 percent and was not significant.

Tables 13 through 16 show the impact of FFS participation on agricultural per capita income in Kenya (Table 13), Tanzania (Table 14), Uganda (Table 15), and on all three countries combined (Table 16). The tables use PSM estimators and covariate matching with ATT to provide more rigorous evidence of the differences in agricultural income between FFS and non-FFS members, and according to gender, land size, and education level of household head. 
Figure 10. Impact of FFS participation on per capita agricultural income across countries

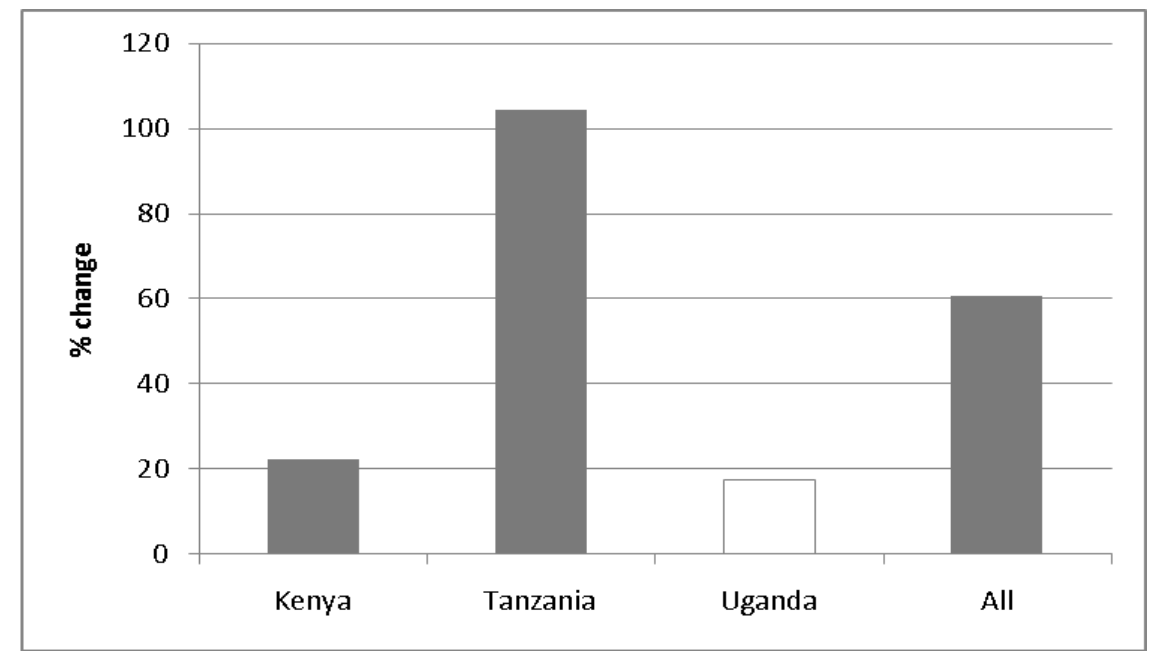

Notes: Bars without fill indicate impact not significant at the $10 \%$ level.

For details showing the mean and median levels of value of crop production, livestock income, and total agricultural income before and after FFS participation as well as the ATT estimates, see Appendix Tables B.1 through B.7.

Table 13. Impact of FFS participation on agricultural income per capita in Kenya (Kenyan shillings)

\begin{tabular}{|c|c|c|c|c|}
\hline & $\begin{array}{c}\text { Kernel } \\
\text { matching } \\
\text { ATT }\end{array}$ & $\begin{array}{c}\text { Nearest-neighbor } \\
\text { matching } \\
\text { ATT }\end{array}$ & $\begin{array}{c}\text { Covariate } \\
\text { matching } \\
\text { ATT }\end{array}$ & $\begin{array}{c}\% \\
\text { change }\end{array}$ \\
\hline FFS versus non-FFS members & 1,068 & 1,697 & $2,675^{*}$ & $21 \% *$ \\
\hline Female-headed households & $-7,272$ & $-2,821$ & $41,618 * * *$ & $332 \% * * *$ \\
\hline Male-headed households & $-2,494$ & $-1,978$ & -858 & $7 \%$ \\
\hline Land-poor & $-6,172$ & $-3,092$ & $-6,752 * * *$ & $-62 \% * * *$ \\
\hline Land-middle & 3,541 & 10,636 & $20,542 * * *$ & $155 \% * * *$ \\
\hline Land-rich & $-8,422$ & $-2,982$ & $-6,032 *$ & $-52 \% *$ \\
\hline Education-none & 28,555 & 15,327 & $51,903 * * *$ & $442 \% * * *$ \\
\hline Education-primary & 4,230 & 5,589 & $12,194 * * *$ & $133 \% * * *$ \\
\hline Education-secondary & $-34,163$ & $-5,722$ & $-27,802 * * *$ & $-226 \% * * *$ \\
\hline
\end{tabular}

Note: $* * *$, and $* * *$ indicate significance at the $0.10,0.05$, and 0.01 levels respectively. 
Table 14. Impact of FFS participation on agricultural income per capita in Tanzania (Tanzanian shillings)

\begin{tabular}{|c|c|c|c|c|}
\hline & \multicolumn{2}{|c|}{ Propensity score matching estimators } & \multirow{2}{*}{$\begin{array}{c}\text { Non-propensity score } \\
\text { matching estimator } \\
\text { Covariate matching } \\
\text { ATT }\end{array}$} & \multirow[t]{2}{*}{$\%$ change } \\
\hline & $\begin{array}{c}\text { Kernel } \\
\text { matching } \\
\text { ATT }\end{array}$ & $\begin{array}{c}\text { Nearest-neighbor } \\
\text { matching } \\
\text { ATT }\end{array}$ & & \\
\hline $\begin{array}{l}\text { FFS versus non-FFS } \\
\text { members }\end{array}$ & 6,621 & $7,045^{* *}$ & $9,644 * *$ & $104 \% * *$ \\
\hline $\begin{array}{l}\text { Female-headed } \\
\text { households }\end{array}$ & 16,044 & 14,957 & $30,536 * * *$ & $155 \% * * *$ \\
\hline $\begin{array}{l}\text { Male-headed } \\
\text { households }\end{array}$ & $9,205 * * *$ & $7,441 * *$ & $7,910 *$ & $104 \%$ \\
\hline Land-poor & -230 & 3,100 & 2,219 & $26 \%$ \\
\hline Land-middle & 6,324 & $10,412 * *$ & 10,305 & $98 \%$ \\
\hline Land-rich & 8,123 & 8,007 & $23,506 * * *$ & $297 \% * * *$ \\
\hline Education-none & $27,535 * *$ & $24,701 *$ & $14,686 * * *$ & $213 \% * * *$ \\
\hline Education-primary & $11,089 * * *$ & $9,207 * *$ & $8,610 *$ & $96 \% * * *$ \\
\hline Education-secondary & 13,787 & $-1,795$ & $-115,565 * * *$ & $87.6 \%$ \\
\hline
\end{tabular}

Note: $* * *$, and $* * *$ indicate significance at the $0.10,0.05$, and 0.01 levels respectively.

Table 15. Impact of FFS participation on agricultural income per capita in Uganda (Ugandan shillings)

\begin{tabular}{|c|c|c|c|c|}
\hline & \multicolumn{2}{|c|}{ Propensity score matching estimators } & \multirow{2}{*}{$\begin{array}{c}\text { Covariate matching } \\
\text { ATT }\end{array}$} & \multirow{2}{*}{$\begin{array}{c}\text { \% change } \\
\text { (covariate matching) }\end{array}$} \\
\hline & $\begin{array}{c}\text { Kernel } \\
\text { matching } \\
\text { ATT }\end{array}$ & $\begin{array}{c}\text { Nearest-neighbor } \\
\text { matching } \\
\text { ATT }\end{array}$ & & \\
\hline $\begin{array}{l}\text { FFS versus non-FFS } \\
\text { members }\end{array}$ & $-3,871$ & 2,954 & 5,998 & $18 \%$ \\
\hline Female-headed households & 27,617 & 27,693 & 26,770 & $36 \%$ \\
\hline Male-headed households & $-14,837$ & $-3,634$ & $11,318 * *$ & $41 \% * *$ \\
\hline Land-poor & $-6,854$ & 1,778 & -510 & $-4 \%$ \\
\hline Land-middle & $-139,973$ & 15,629 & $31,306 * * *$ & $79 \% * * *$ \\
\hline Land-rich & $-14,939$ & $-17,350$ & $-11,755^{* * *}$ & $-25 \% * * *$ \\
\hline Education-none & $10,984 * * *$ & $10,920 * * *$ & $7,704 * * *$ & $43 \% * * *$ \\
\hline Education-primary & 3,843 & 14,044 & $46,994 * * *$ & $114 \% * * *$ \\
\hline Education-secondary & $-71,305^{* * *}$ & $-13,519$ & $-19,911$ & $-70 \% * * *$ \\
\hline
\end{tabular}

Note: $* * *$, and $* * *$ indicate significance at the $0.10,0.05$, and 0.01 levels, respectively. 
Table 16. Impact of FFS on agricultural income per capita in all countries (U.S. dollars)

\begin{tabular}{|c|c|c|c|c|c|}
\hline & $\begin{array}{c}\text { Per capita agricultural } \\
\text { income of FFS members } \\
\text { before FFS }\end{array}$ & $\begin{array}{c}\text { Kernel } \\
\text { matching } \\
\text { ATT }\end{array}$ & $\begin{array}{c}\text { Nearest- } \\
\text { neighbor } \\
\text { matching } \\
\text { ATT }\end{array}$ & $\begin{array}{l}\text { Covariate } \\
\text { matching } \\
\text { ATT }\end{array}$ & $\begin{array}{c}\% \\
\text { change }\end{array}$ \\
\hline $\begin{array}{l}\text { FFS versus non-FFS } \\
\text { members }\end{array}$ & 75.2 & 17.6 & 35.1 & $45.7 * *$ & $61 \% * *$ \\
\hline $\begin{array}{l}\text { Female-headed } \\
\text { households }\end{array}$ & 100.8 & 81.1 & 84.3 & $188.9 * * *$ & $187 \% * * *$ \\
\hline $\begin{array}{l}\text { Male-headed } \\
\text { households }\end{array}$ & 70.8 & -51.9 & -0.3 & -26.3 & $-37 \%$ \\
\hline Land-poor & 83.4 & 22.6 & 18.5 & 29.8 & $38 \%$ \\
\hline Land-middle & 96.2 & 19.6 & $22.3^{*}$ & $22.9 * *$ & $24 \% * *$ \\
\hline Land-rich & 44.0 & 8.7 & 6.7 & 0.04 & $15 \%$ \\
\hline Education-none & 78.5 & 213.3 & 179.3 & $176.1 * * *$ & $227 \% * * *$ \\
\hline Education-primary & 59.5 & 31.6 & $48.9 * *$ & $62.3 * * *$ & $105 \% * * *$ \\
\hline Education-secondary & 101 & 58.8 & -114.6 & $-158.9^{*}$ & $156 \%$ \\
\hline
\end{tabular}

Note:*, $* *$, and $* * *$ indicate significance at the $0.10,0.05$, and 0.01 levels, respectively.

\section{Impact on Agricultural Income across Gender}

As expected, the impact of FFS participation on agricultural income across gender, land resource endowment, and level of education differed significantly. These results are consistent with those obtained under crop and livestock income, since agricultural income, as used in this report, is a sum of the two sectors. At the regional level (all three countries combined), per capita agricultural income of femaleheaded FFS households increased by 187 percent, whereas per capita agricultural income of male-headed FFS households fell—but the fall was not statistically significant at 10 percent (Figure 11). The increase in per capita income for female-headed FFS households was greater than for male-headed FFS households both in absolute value (ATT) and percentage-wise. Agricultural income of female-headed households participating in FFSs increased the most in Kenya (332 percent), but male-headed agricultural income did not change significantly. Similarly, the agricultural income of female-headed households in Tanzania increased by 155 percent, but male-headed household agricultural income did not change significantly. The changes in ATT — which is the absolute change due to participation in the field schools - were also greater for female-headed FFS households than for male-headed FFS households in the region, Kenya, and Tanzania.

The agricultural income of female-headed households participating in FFSs did not change significantly in Uganda, but male-headed household income in the country increased by 41 percent. As discussed earlier, however, livestock income among female-headed households increased the most in Uganda (187 percent). These results demonstrate that participation in an FFS increased agricultural income of female-headed households more than male-headed households. The results suggest that the FFS approach could serve as a key strategy to provide agricultural extension services to female farmers whose access to agricultural extension in Sub-Saharan Africa is generally poor. 
Figure 11. Impact of FFS participation across gender of household head (\% change in agricultural income per capita)

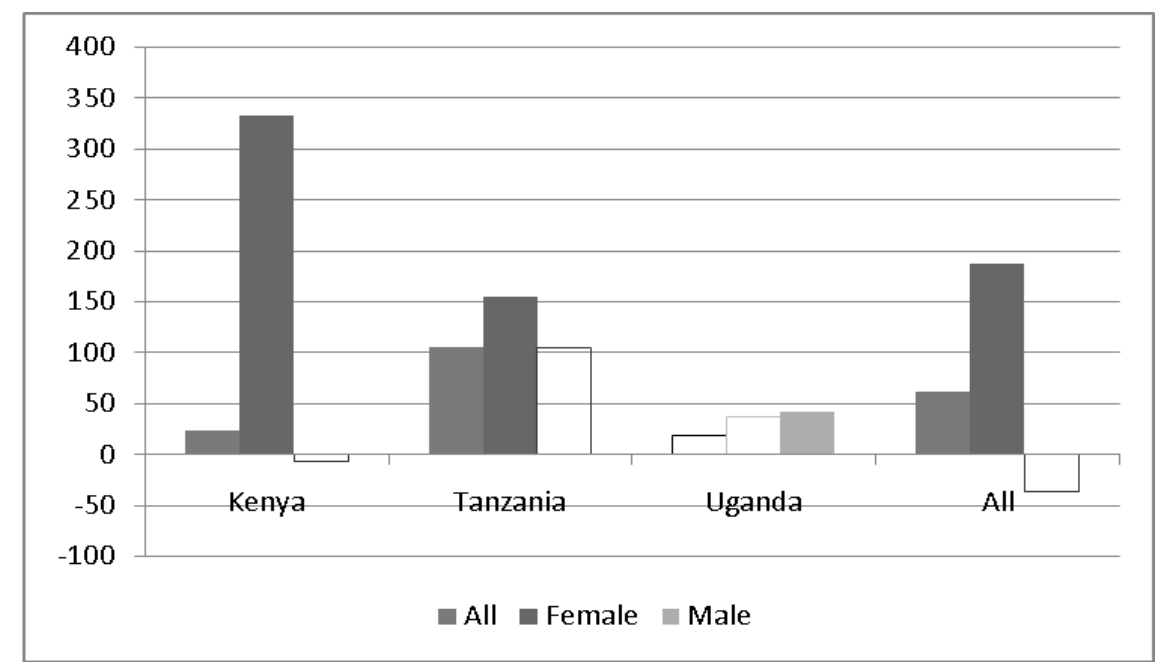

Notes: Bars without fill indicate impact not significant at the $10 \%$ level.

For details showing the mean and median levels of value of crop production, livestock income, and total agricultural income before and after FFS participation as well as the ATT estimates, see Appendix Tables B.1 through B.7.

\section{Impact on Agricultural Income across Land Poverty Terciles}

The impact of FFS participation across land poverty terciles generally shows that the effect on agricultural income of households farming the smallest land areas was either nonsignificant (all countries combined, Tanzania, and Uganda) or negative (Kenya) (Figure 12). The middle land area tercile showed a significant increase in agricultural income for all countries combined (24 percent), Kenya (155 percent), and Uganda (79 percent). Agricultural income of farmers in the largest land area tercile increased significantly only in Tanzania (297 percent) and declined in Kenya (by 52 percent) and Uganda (by 25 percent). The results suggest that when poverty is measured using land area, the FFS approach had a limited impact on the poorest farmers.

Figure 12. Impact of FFS participation on agricultural income across land poverty terciles

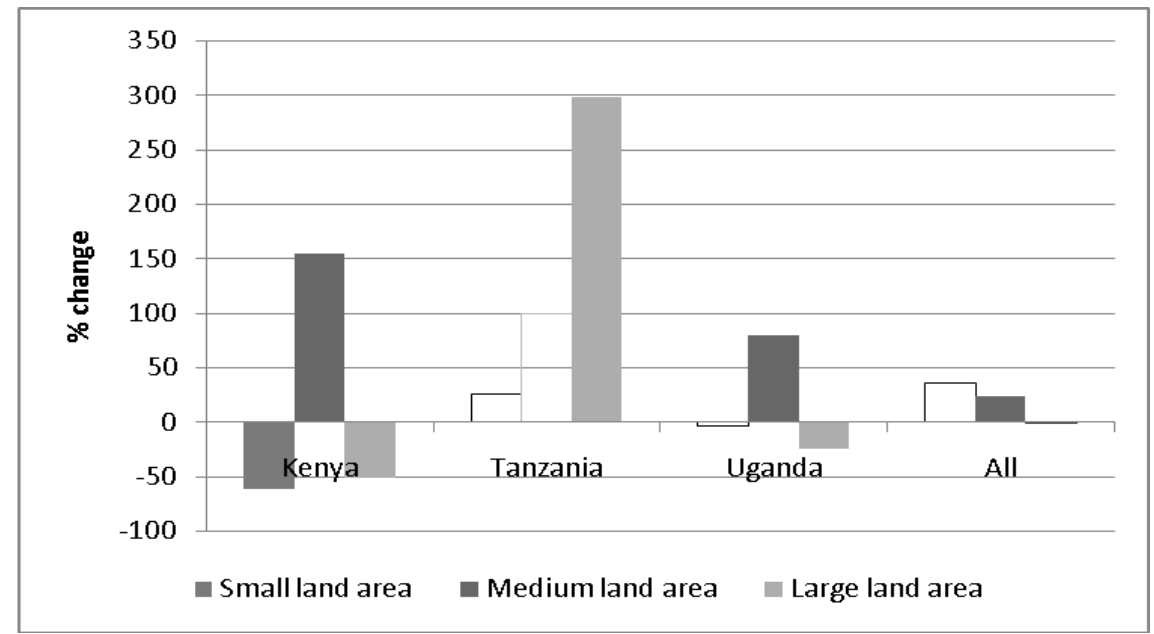

Notes: Bars without fill indicate impact not significant at the $10 \%$ level.

For details showing the mean and median levels of value of crop production, livestock income, and total agricultural income before and after FFS participation as well as the ATT estimates, see Appendix Tables B.1 through B.7. 


\section{Impact on Agricultural Income across Level of Education of Household Head}

The impact of FFS participation across education-level groups shows that per capita agricultural income of households whose head had no formal education increased more than the case for other education groups. For all three countries combined, agricultural income of households whose head had no formal education increased by more than 200 percent (Figure 13). In all three countries, agricultural income increased significantly by at least 43 percent (Uganda) and at most 442 percent (Kenya) for households whose head had no formal education. Similarly, agricultural income of households whose head had primary education increased by at least 96 percent (Tanzania) and at most 114 percent (Uganda). The impact on agricultural income for households whose head had secondary education was generally weak (nonsignificant for all three countries combined and in Tanzania) or negative (-225 percent in Kenya and 70 percent in Uganda). The results suggest that FFSs were accessible to farmers with limited education. This is contrary to the case of conventional agricultural extension, which is more accessible to the bettereducated farmers (Feder and Zilberman 1985).

Figure 13. Impact of FFS participation on agricultural income across education level of household head

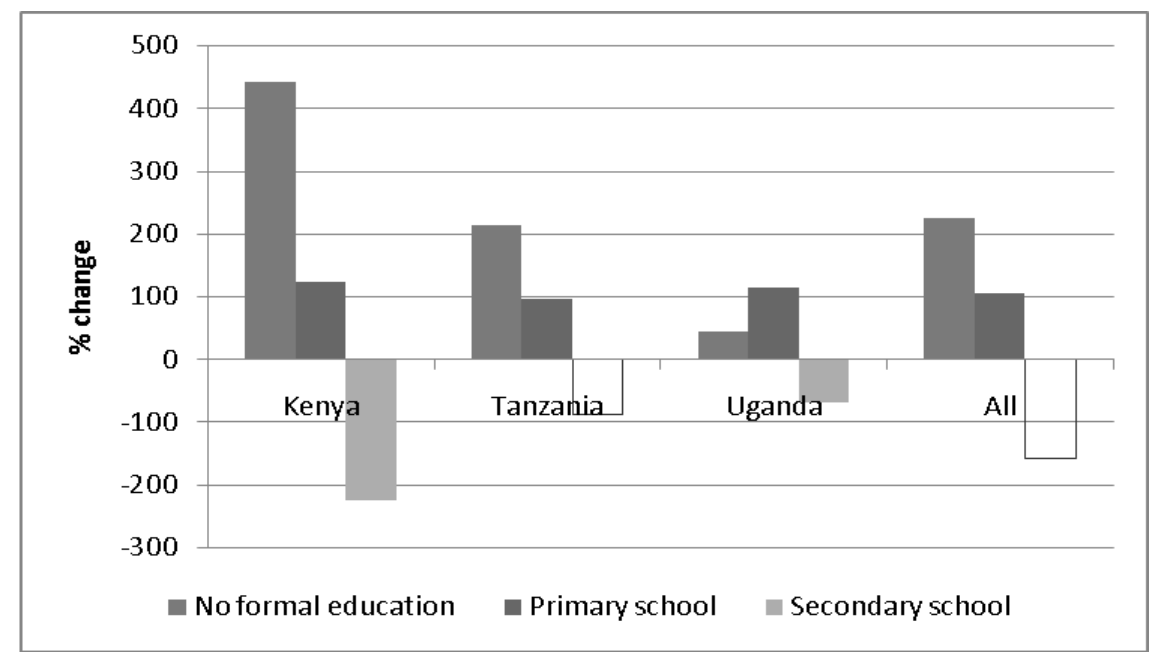

Notes: Bars without fill indicate impact not significant at the $10 \%$ level.

For details showing the mean and median levels of value of crop production, livestock income, and total agricultural income before and after FFS participation as well as the ATT estimates, see Appendix Tables B.1 through B.7.

\section{Summary}

In summary, Figure 14 shows the impact of FFS participation on value of crops produced per acre, livestock value gain per capita, and agricultural income per capita. It is evident that such participation led to increased production, productivity, and income in nearly all cases. The most significant changes were seen in Kenya for crops ( 80 percent) and in Tanzania for agricultural income (more than 100 percent). All three countries combined also showed significant changes due to the FFSs. This shows the overall project impact. In Uganda, the increases are not significant. As mentioned earlier, that is likely attributable to the National Agricultural Advisory Services NAADS project that was taking place in the same districts as the FFS project, which could have led to a dilution of the effects on non-FFS participants. Other NGOs or programs in agriculture may have had a moderating effect or complementary effect as well. 
Figure 14. Impact of FFS participation on value of crops produced per acre, livestock value gain per capita, and agricultural income per capita

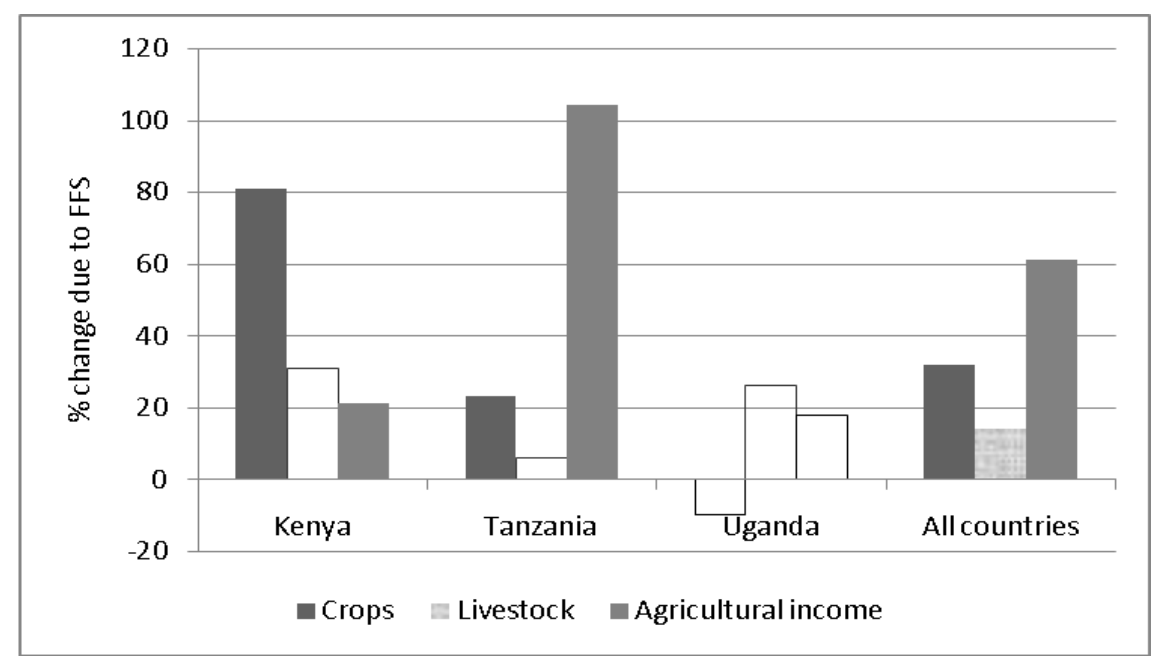

Notes: Bars without fill indicate impact not significant at the $10 \%$ level.

For details showing the mean and median levels of value of crop production, livestock income, and total agricultural income before and after FFS participation as well as the ATT estimates, see Appendix Tables B.1 through B.7. 


\section{CONCLUSIONS AND POLICY IMPLICATIONS}

This study provides crucial insights into and important evidence on the impact of farmer field schools in the East Africa region. Using matching estimators (propensity score matching and covariate matching) with a double-difference approach, the study evaluated an FFS project funded by IFAD and implemented by FAO and local government ministries in Kenya, Tanzania, and Uganda between 1999 and 2008. The study is unique in the use of such quasi-experimental approaches in a longitudinal design to more rigorously assess the impact of a multicountry FFS program.

The goal of the study was to provide robust evidence for policymakers, donors, farmers, and implementation actors on whether and how the FFS approach can contribute to poverty alleviation and productivity. We set the following specific objectives:

1. Examine participation in the FFSs, especially the extent to which poor people, women, and other marginalized groups take part in the schools.

2. Examine the effects of farmer field schooling on outcomes such as poverty, gender, and productivity, and the role that household-capital-endowment-level social characteristics have on access and use/maximization of benefits of the FFS approach.

Henceforth we summarize the findings on each of the objectives, and then offer some policy recommendations based on those results.

\section{Farmer Field School Participation}

The results of a household survey in the three countries revealed that 50 percent of the FFS project members were female, and the majority of participants (66 percent) had achieved up to primary level of education but no further. The main reasons respondents gave for not joining an FFS include lack of time and lack of information.

The factors affecting FFS participation differed across the three countries. Farmers belonging to savings and credit groups and farmer groups other than an FFS were more likely to participate in the FFS program than those who did not. The results demonstrate the importance of farmer groups in helping farmers access rural services. Younger farmers were more likely to participate in the FFS program than older farmers. The level of education of the household head had mixed impact on the propensity to participate. Overall, the level of education of the household head did not have a significant impact on the probability to participate in an FFS. In Kenya, however, households whose head had primary or secondary education were more likely to participate in an FFS than farmers with no formal education. The contrary was the case in Uganda - that is, household heads with primary or secondary education were less likely to participate in an FFS than those with no formal education. Controlling for the level of education of the household head and other factors, the level of education of the spouse of the household head also affected the probability to participate. Households whose head was married to a spouse with no formal education were more likely to participate in the FFS program than those whose head was married to a spouse with primary education for all countries combined, in Tanzania, and in Uganda. With the exception of Kenya, these results suggest that FFSs are accessible to households with low levels of education.

Proximity to tarmac roads had a strong impact on the probability to participate in the FFS project. For all countries combined and for Kenya, farmers closer to tarmac roads were more likely to participate than those living in remote areas. Controlling for access to tarmac roads and other covariates, distance to urban areas was positively associated with participation in an FFS in all countries combined and in Kenya and Tanzania. These results underscore the importance of roads in ensuring agricultural rural services even for farmers in remote areas. The Ugandan results show contrasting characteristics: distance to was positively associated with participation in FFS but distance to urban areas was negatively associated with participation in FFS. . Even though these results may be related to project placement bias, they demonstrate the potential for the FFS program to work under different socioeconomic environments. 


\section{Impacts of Participation on Various Outcomes}

The impact of FFS participation differed significantly across gender, land resource endowment, and level of education. At the regional (project) level, per capita agricultural income of female-headed households increased by 189 percent, while the equivalent increase for male-headed households was only 14 percent (and was not statistically significant at the 10 percent level). Crop productivity and per capita agricultural income of female-headed households participating in the FFS project increased significantly in Kenya and Tanzania, but the per capita agricultural income increase for male-headed households was not significant at the regional level and in Kenya and Tanzania. In Uganda, livestock income for female-headed households also increased significantly more than for male-headed households. These results demonstrate that the FFS approach was more beneficial for female-headed households than for male-headed households. The results suggest that the FFS approach could serve as a key strategy to provide agricultural extension services to female farmers whose access to agricultural extension in Sub-Saharan Africa is generally poor.

The results also show that the per capita agricultural income of FFS households whose head had no formal education increased more than of those with primary, secondary, or tertiary education. The impact of farmer field schooling on agricultural income for households whose head had secondary education was generally weak or negative. The results thus suggest that the FFS project was accessible to farmers with limited education. These results are consistent with the results on the probability to participate in an FFS, which also showed that farmers with lower levels of education were more likely to participate than those with higher education.

The impact of FFSs across land poverty terciles generally shows that the effect on per capita agricultural income of households with the smallest land area was either nonsignificant or negative. The impact of farmer field schooling on crop productivity and per capita agricultural income was significant for the middle land area tercile. The results suggest that when poverty is measured using land area, the FFS approach had limited impact on the poorest farmers but had a significant impact on farmers with a medium-size land area.

\section{Policy Implications}

As the preceding italicized statements suggest, the following policy implications may be drawn as a result of this study:

1. It is important to support farmer organizations as a major vehicle for farmer development. In this study, farmer groups proved to be important in helping farmers access rural services. This is in line with other research in the region (see, e.g., Davis 2004; Place et al. 2002; Stringfellow et al. 1997).

2. The FFS program not only allowed women to participate but led to significant benefits in terms of income and crop and livestock production.

Women constituted 50 percent of participants in the project. The FFS program appeared to be more beneficial for female-headed households than for male-headed households. FFS programs can be used to provide agricultural extension services to women, who contribute the most in agricultural production and yet have poor access to agricultural extension services compared with male farmers. It has been shown that women gain greater benefits than men when they have access to the same inputs (Saito, Mekonnen, and Spurling 1994). The FFS approach can thus be used to target women farmers and female-headed households while still reaching men.

3. The FFS program not only allowed people with low education to participate but led to significant benefits in terms of income and crop and livestock productivity.

The FFS program can be used to target low-education groups. This is contrary to the conventional wisdom, which says that FFSs are better suited for people with higher education levels, because of the semiformal nature of the education that takes place. Apparently the demonstration sites, 
experiential learning methods, group approaches, and other factors make up for this and allow low-literacy people to participate and benefit.

4. The FFS approach had the most beneficial effects on farmers with medium-size land areas. The program showed limited impact on farmers with the poorest (smallest) land size, but it had a significant impact on farmers with medium-size land areas (relative to the area). This is also important when targeting groups. Farmers with the smallest land size may not have enough land to experiment on, or they may be too busy working on other people's land to be able to participate fully in the FFS. Farmers with larger land size may not have the need to participate in programs such as FFS that are geared toward reducing poverty. The time needed to participate in the FFS may also prohibit larger-scale land owners from participating.

5. It is important to invest in infrastructure in rural areas.

The study showed that in most cases, farmers who were near tarmac roads were more likely to participate in an FFS. Roads are important in ensuring agricultural services even for remote areas . Roads reduce the cost of transport to markets and other urban centers, and they allow farmers to get produce to market more quickly and cheaply.

6. The FFS program has the potential to be effective under different agro-ecosystems, livelihoods, and farming systems.

In Uganda, the FFS program attracted participants who were farmed far from tarmac roads but relatively close to urban areas, whereas in the other study countries the opposite was true. As increased focus is put on extension in general and FFSs in particular, it is more important than ever to implement programs and policies that suit the local conditions, including the policy environment, farming systems, and capacity of service providers and communities. Rather than blanketing areas with a one-size-fits-all extension approach, it is important to come up with sensible and smart "best fit" solutions (Birner et al. 2006; Davis 2006). The FFS program has shown itself to be effective in a variety of situations. 


\section{APPENDIX A: BALANCING TESTS}

Table A.1. Kenya

\begin{tabular}{|c|c|c|c|c|c|c|}
\hline Variable & Sample & Treated & Control & $\%$ bias & Bias & $p>t$ \\
\hline \multicolumn{7}{|l|}{ Household human capital endowment } \\
\hline & Unmatched & 0.15658 & 0.17949 & -6.1 & & 0.574 \\
\hline Female household head & Matched & 0.16 & 0.13108 & 7.7 & -26.3 & 0.337 \\
\hline \multicolumn{7}{|c|}{ Level of education of household head (cf. no formal education) } \\
\hline \multirow{3}{*}{ Primary } & Unmatched & 0.51601 & 0.62393 & -21.9 & & $0.049^{* *}$ \\
\hline & Matched & 0.52364 & 0.51728 & 1.3 & 94.1 & 0.882 \\
\hline & Unmatched & 0.32384 & 0.20513 & 27.1 & & $0.017 * *$ \\
\hline \multirow[t]{2}{*}{ Secondary } & Matched & 0.32 & 0.33566 & -3.6 & 86.8 & 0.696 \\
\hline & Unmatched & 0.07829 & 0.05128 & 11 & & 0.338 \\
\hline Postsecondary & Matched & 0.07273 & 0.08307 & -4.2 & 61.7 & 0.651 \\
\hline \multicolumn{7}{|c|}{ Level of education of spouse of household head (cf. no formal education) } \\
\hline \multirow{3}{*}{ Primary } & Unmatched & 0.54093 & 0.57265 & -6.4 & & 0.563 \\
\hline & Matched & 0.54909 & 0.61939 & -14.1 & -121.6 & $0.095^{*}$ \\
\hline & Unmatched & 0.17438 & 0.08547 & 26.6 & & $0.023 * *$ \\
\hline \multirow[t]{2}{*}{ Secondary } & Matched & 0.17091 & 0.12636 & 13.3 & 49.9 & 0.142 \\
\hline & Unmatched & 0.01779 & 0.02564 & -5.4 & & 0.612 \\
\hline \multirow[t]{2}{*}{ Postsecondary } & Matched & 0.01818 & 0.02569 & -5.1 & 4.4 & 0.549 \\
\hline & Unmatched & 0.97153 & 0.83761 & 46.6 & & $0.000 * * *$ \\
\hline \multirow[t]{2}{*}{ Membership in non-FFS groups } & Matched & 0.97455 & 0.98377 & -3.2 & 93.1 & 0.45 \\
\hline & Unmatched & 0.879 & 0.89744 & -5.8 & & 0.601 \\
\hline \multirow[t]{2}{*}{ Off-farm income } & Matched & 0.88 & 0.86799 & 3.8 & 34.9 & 0.672 \\
\hline & Unmatched & 3.8466 & 3.8947 & -18.8 & & $0.095^{*}$ \\
\hline \multirow[t]{2}{*}{ Ln (head age) } & Matched & 3.856 & 3.8385 & 6.8 & 63.6 & 0.415 \\
\hline & Unmatched & -0.12849 & 0.07071 & -38.2 & & $0.001 * * *$ \\
\hline \multirow[t]{2}{*}{ Ln (household size) } & Matched & -0.10719 & -0.09443 & -2.4 & 93.6 & 0.762 \\
\hline & Unmatched & 0.53185 & 0.52442 & 3.7 & & 0.736 \\
\hline Dependency ratio & Matched & 0.53747 & 0.52974 & 3.9 & -3.9 & 0.65 \\
\hline \multicolumn{7}{|l|}{ Access to rural services } \\
\hline \multirow{3}{*}{ Member credit and saving organization } & Unmatched & 0.70819 & 0.41026 & 62.7 & & $0.000 * * *$ \\
\hline & Matched & 0.70545 & 0.71618 & -2.3 & 96.4 & 0.782 \\
\hline & Unmatched & 1.8235 & 1.8438 & -1.9 & & 0.862 \\
\hline \multirow[t]{2}{*}{$\log$ (distance to tarmac road) } & Matched & 1.8438 & 1.9674 & -11.7 & -508.9 & 0.147 \\
\hline & Unmatched & 1.4759 & 1.2741 & 23.2 & & $0.032 * *$ \\
\hline \multirow[t]{2}{*}{ Log (distance to market/town) } & Matched & 1.4745 & 1.5035 & -3.3 & 85.6 & 0.682 \\
\hline & Unmatched & 1.0359 & 0.97752 & 7.4 & & 0.483 \\
\hline Log (land) & Matched & 1.0413 & 1.0533 & -1.5 & 79.5 & 0.865 \\
\hline
\end{tabular}

Note: $*, * *$, and $* * *$ indicate significance at the $0.10,0.05$, and 0.01 levels respectively. 
Table A.2. Tanzania

\begin{tabular}{|c|c|c|c|c|c|c|}
\hline Variable & Sample & Treated & Control & $\%$ bias & Bias & $p>t$ \\
\hline \multicolumn{7}{|l|}{ Household human capital endowment } \\
\hline & Unmatched & 0.13971 & 0.13084 & 2.6 & & 0.822 \\
\hline Female household head & Matched & 0.14022 & 0.10389 & 10.6 & -309.8 & 0.198 \\
\hline \multicolumn{7}{|c|}{ Level of education of household head (cf. no formal education) } \\
\hline \multirow{3}{*}{ Primary } & Unmatched & 0.77941 & 0.72897 & 11.7 & & 0.298 \\
\hline & Matched & 0.7786 & 0.73161 & 10.9 & 6.8 & 0.205 \\
\hline & Unmatched & 0.12132 & 0.13084 & -2.9 & & 0.801 \\
\hline \multirow[t]{2}{*}{ Secondary } & Matched & 0.12177 & 0.18105 & -17.8 & -522.8 & $0.055^{*}$ \\
\hline & Unmatched & 0.01103 & 0.02804 & -12.3 & & 0.234 \\
\hline Postsecondary & Matched & 0.01107 & 0.0092 & 1.3 & 89 & 0.829 \\
\hline \multicolumn{7}{|c|}{ Level of education of spouse of household head (cf. no formal education) } \\
\hline \multirow{3}{*}{ Primary } & Unmatched & 0.84191 & 0.86916 & -7.7 & & 0.505 \\
\hline & Matched & 0.84502 & 0.89734 & -14.8 & -92 & $0.07 *$ \\
\hline & Unmatched & 0.04779 & 0.06542 & -7.6 & & 0.491 \\
\hline \multirow[t]{2}{*}{ Secondary } & Matched & 0.04797 & 0.04863 & -0.3 & 96.2 & 0.971 \\
\hline & Unmatched & 0 & 0 & & & \\
\hline \multirow[t]{2}{*}{ Postsecondary } & Matched & 0 & 0 & & . & . \\
\hline & Unmatched & 0.98897 & 0.92523 & 31.7 & & $0.001 * * *$ \\
\hline \multirow[t]{2}{*}{ Membership in non-FFS groups } & Matched & 0.98893 & 0.98477 & 2.1 & 93.5 & 0.672 \\
\hline & Unmatched & 0.88971 & 0.78505 & 28.5 & & $0.008 * * *$ \\
\hline \multirow[t]{2}{*}{ Off-farm income } & Matched & 0.8893 & 0.90244 & -3.6 & 87.4 & 0.618 \\
\hline & Unmatched & 3.7729 & 3.8353 & -20.4 & & $0.072 *$ \\
\hline \multirow[t]{2}{*}{ Ln (head age) } & Matched & 3.7738 & 3.7796 & -1.9 & 90.6 & 0.819 \\
\hline & Unmatched & 1.6987 & 1.6288 & 13.1 & & 0.241 \\
\hline \multirow[t]{2}{*}{ Ln (household size) } & Matched & 1.6978 & 1.6552 & 8 & 39.1 & 0.309 \\
\hline & Unmatched & 0.51428 & 0.48346 & 14.1 & & 0.197 \\
\hline Dependency ratio & Matched & 0.51459 & 0.50694 & 3.5 & 75.2 & 0.661 \\
\hline \multicolumn{7}{|l|}{ Access to rural services } \\
\hline \multirow{3}{*}{ Member credit and saving organization } & Unmatched & 0.36397 & 0.18692 & 40.3 & & $0.001 * * *$ \\
\hline & Matched & 0.36162 & 0.39976 & -8.7 & 78.5 & 0.362 \\
\hline & Unmatched & 1.5416 & 1.3114 & 15.2 & & 0.191 \\
\hline \multirow[t]{2}{*}{ Log (distance to tarmac road) } & Matched & 1.5359 & 1.4275 & 7.2 & 52.9 & 0.411 \\
\hline & Unmatched & 1.8752 & 1.924 & -4.3 & & 0.695 \\
\hline \multirow[t]{2}{*}{ Log (distance to market/town) } & Matched & 1.8781 & 1.7654 & 9.8 & -130.9 & 0.252 \\
\hline & Unmatched & 0.62878 & 0.65834 & -4 & & 0.726 \\
\hline Log (land) & Matched & 0.62854 & 0.54865 & 10.9 & -170.3 & 0.255 \\
\hline
\end{tabular}

Note: $* * *$, and $* * *$ indicate significance at the $0.10,0.05$, and 0.01 levels respectively. 
Table A.3. Uganda

\begin{tabular}{|c|c|c|c|c|c|c|c|}
\hline Variable & Sample & Treated & Control & $\%$ bias & Bias & $t$ & $p>t$ \\
\hline \multicolumn{8}{|l|}{ Household human capital endowment } \\
\hline & Unmatched & 0.14719 & 0.17797 & -8.3 & & -0.75 & 0.457 \\
\hline Female household head & Matched & 0.14884 & 0.19557 & -12.6 & -51.8 & -1.28 & 0.2 \\
\hline \multicolumn{8}{|c|}{ Level of education of household head (cf. no formal education) } \\
\hline \multirow{3}{*}{ Primary } & Unmatched & 0.57576 & 0.50847 & 13.5 & & 1.2 & 0.233 \\
\hline & Matched & 0.55814 & 0.47616 & 16.4 & -21.8 & 1.7 & $0.089 *$ \\
\hline & Unmatched & 0.25108 & 0.35593 & -22.9 & & -2.06 & 0.041 \\
\hline \multirow[t]{2}{*}{ Secondary } & Matched & 0.26512 & 0.33524 & -15.3 & 33.1 & -1.59 & 0.113 \\
\hline & Unmatched & 0.09957 & 0.09322 & 2.1 & & 0.19 & 0.85 \\
\hline Postsecondary & Matched & 0.10698 & 0.1125 & -1.9 & 13 & -0.18 & 0.855 \\
\hline \multicolumn{8}{|c|}{ Level of education of spouse of household head (cf. no formal education) } \\
\hline \multirow{3}{*}{ Primary } & Unmatched & 0.5974 & 0.65254 & -11.4 & & -1 & 0.318 \\
\hline & Matched & 0.62326 & 0.58348 & 8.2 & 27.9 & 0.84 & 0.4 \\
\hline & Unmatched & 0.11255 & 0.12712 & -4.5 & & -0.4 & 0.69 \\
\hline \multirow[t]{2}{*}{ Secondary } & Matched & 0.12093 & 0.12661 & -1.7 & 61 & -0.18 & 0.859 \\
\hline & Unmatched & 0.00433 & 0.02542 & -17.4 & & -1.75 & $0.08^{*}$ \\
\hline \multirow[t]{2}{*}{ Postsecondary } & Matched & 0.00465 & 0.00467 & 0 & 99.9 & 0 & 0.998 \\
\hline & Unmatched & 0.93506 & 0.76271 & 49.4 & & 4.77 & $0.000 * * *$ \\
\hline \multirow[t]{2}{*}{ Membership in non-FFS groups } & Matched & 0.93023 & 0.9391 & -2.5 & 94.9 & -0.37 & 0.711 \\
\hline & Unmatched & 0.87013 & 0.88136 & -3.4 & & -0.3 & 0.766 \\
\hline \multirow[t]{2}{*}{ Off-farm income } & Matched & 0.87907 & 0.89579 & -5.1 & -48.9 & -0.55 & 0.584 \\
\hline & Unmatched & 3.7851 & 3.7645 & 7.6 & & 0.68 & 0.494 \\
\hline \multirow[t]{2}{*}{ Ln (head age) } & Matched & 3.7818 & 3.7874 & -2.1 & 72.4 & -0.23 & 0.819 \\
\hline & Unmatched & 1.9078 & 1.847 & 10.4 & & 0.94 & 0.348 \\
\hline \multirow[t]{2}{*}{ Ln (household size) } & Matched & 1.9107 & 1.956 & -7.8 & 25.4 & -0.82 & 0.415 \\
\hline & Unmatched & 0.54529 & 0.52755 & 8.1 & & 0.73 & 0.467 \\
\hline Dependency ratio & Matched & 0.5438 & 0.54602 & -1 & 87.5 & -0.11 & 0.914 \\
\hline \multicolumn{8}{|l|}{ Access to rural services } \\
\hline \multirow{3}{*}{ Member credit and saving organization } & Unmatched & 0.67532 & 0.37288 & 63.3 & & 5.63 & $0.000 * * *$ \\
\hline & Matched & 0.66047 & 0.71753 & -12 & 81.1 & -1.28 & 0.202 \\
\hline & Unmatched & 0.29182 & 0.46343 & -14.6 & & -1.23 & 0.219 \\
\hline \multirow[t]{2}{*}{ Log (distance to tarmac road) } & Matched & 0.34521 & 0.56142 & -18.4 & -26 & -1.96 & $0.05^{* *}$ \\
\hline & Unmatched & 1.1733 & 0.9751 & 21.1 & & 1.83 & 0.068 \\
\hline \multirow[t]{2}{*}{ Log (distance to market/town) } & Matched & 1.1063 & 1.1647 & -6.2 & 70.5 & -0.66 & 0.512 \\
\hline & Unmatched & 3.8543 & 3.4998 & 32 & & 2.83 & $0.005^{* * *}$ \\
\hline Log (land) & Matched & 3.8156 & 3.7995 & 1.4 & 95.5 & 0.15 & 0.878 \\
\hline
\end{tabular}

Note: *,**, and $* * *$ indicate significance at the $0.10,0.05$, and 0.01 levels respectively. 
APPENDIX B: VALUE OF CROP PRODUCTION BEFORE AND AFTER FFS

Table B.1. Kenya

\begin{tabular}{|c|c|c|c|c|}
\hline \multirow[b]{2}{*}{ Value of crop production per acre } & \multicolumn{2}{|c|}{2006} & \multicolumn{2}{|c|}{2008} \\
\hline & Mean & Median & Mean & Median \\
\hline FFS member $(n=281)$ & 7,234 & 5,551 & 22,862 & 12,517 \\
\hline Non-FFS member $(n=117)$ & 9,320 & 5,092 & 20,583 & 9,660 \\
\hline FFS member, female headed $(n=44)$ & 5,581 & 5,454 & 23,026 & 11,453 \\
\hline FFS member, male headed $(n=237)$ & 7,529 & 5,600 & 22,833 & 12,551 \\
\hline FFS member, land-poor $(n=117)$ & 7,678 & 5,600 & 27,262 & 12,444 \\
\hline FFS member, land-middle $(n=98)$ & 6,211 & 4,533 & 21,794 & 12,965 \\
\hline FFS member, land-rich $(n=66)$ & 7,973 & 6,100 & 16,673 & 12,603 \\
\hline FFS member, District $2(n=125)$ & 6,455 & 6,333 & 19,199 & 11,182 \\
\hline FFS member, District $3(n=68)$ & 10,740 & 6,057 & 24,452 & 14,601 \\
\hline FFS member, District $4(n=86)$ & 5,524 & 4,360 & 27,290 & 14,506 \\
\hline
\end{tabular}

Table B.2. Tanzania

\begin{tabular}{|c|c|c|c|c|}
\hline \multirow[b]{2}{*}{ Value of production per acre } & \multicolumn{2}{|c|}{2006} & \multicolumn{2}{|c|}{2008} \\
\hline & Mean & Median & Mean & Median \\
\hline FFS member $(n=261)$ & 113,786 & 45,418 & 212,636 & 95,200 \\
\hline Non-FFS members $(n=100)$ & 115,196 & 45,737 & 217,046 & 77,691 \\
\hline FFS member, female headed $(n=36)$ & 160,329 & 69,567 & 270,782 & 122,817 \\
\hline FFS member, male headed $(n=225)$ & 106,339 & 44,571 & 203,333 & 94,871 \\
\hline FFS member, land-poor $(n=99)$ & 133,921 & 73,333 & 262,791 & 115,713 \\
\hline FFS member, land-middle $(n=112)$ & 122,555 & 42,218 & 209,737 & 85,877 \\
\hline FFS member, land-rich $(n=50)$ & 54,276 & 35,358 & 119,823 & 75,111 \\
\hline
\end{tabular}


Table B.3. Uganda

\begin{tabular}{|c|c|c|c|c|}
\hline \multirow[b]{2}{*}{ Value of crop production per acre } & \multicolumn{2}{|c|}{2006} & \multicolumn{2}{|c|}{2008} \\
\hline & Mean & Median & Mean & Median \\
\hline FFS member & 203,010 & 140,162 & 358,779 & 253,295 \\
\hline Non-FFS member & 209,883 & 128,909 & 445,997 & 260,000 \\
\hline FFs member, female headed & 118,618 & 53,636 & 319,075 & 154,418 \\
\hline FFS member, male headed & 217,151 & 153,706 & 365,431 & 275,609 \\
\hline FFS member, land-poor & 160,595 & 132,534 & 221,078 & 150,597 \\
\hline FFS member, land-middle & 207,901 & 150,428 & 411,311 & 290,655 \\
\hline FFS member, land-rich & 232,271 & 107,571 & 417,122 & 294,628 \\
\hline FFS member, District 5 & 177,589 & 150,428 & 393,037 & 330,000 \\
\hline FFS member, District 6 & 105,183 & 56,109 & 188,978 & 127,381 \\
\hline FFS member, District 7 & 308,726 & 209,666 & 457,620 & 283,333 \\
\hline
\end{tabular}

Table B.4. Impact of FFSs in Kenya

\begin{tabular}{|c|c|c|c|c|c|c|c|c|c|}
\hline & $\begin{array}{c}\text { Crop } \\
\text { production } \\
\text { (KES/ } \\
\text { acre) }\end{array}$ & ATT & $\begin{array}{c}\% \\
\text { change }\end{array}$ & $\begin{array}{l}\text { Live-stock } \\
\text { income } \\
\text { (KES) }\end{array}$ & ATT & $\begin{array}{c}\% \\
\text { change }\end{array}$ & $\begin{array}{l}\text { Agricultural } \\
\text { income per } \\
\text { capita (KES) }\end{array}$ & ATT & $\begin{array}{c}\% \\
\text { change }\end{array}$ \\
\hline & Before FFS & & & Before FFS & & & Before FFS & & \\
\hline $\begin{array}{l}\text { All FFS } \\
\text { members }\end{array}$ & 7,234 & 5,860 & 81 & 8,495 & 2,613 & 31 & 11,901 & 2,675 & 22 \\
\hline $\begin{array}{l}\text { Female- } \\
\text { headed } \\
\text { households }\end{array}$ & 5,581 & 4,641 & 83 & 9,566 & 15,202 & 159 & 12,540 & 41,618 & 332 \\
\hline $\begin{array}{l}\text { Male- } \\
\text { headed } \\
\text { households }\end{array}$ & 7,529 & 2,580 & 34 & 8,282 & 550 & 7 & 11,782 & -858 & -7 \\
\hline Land-poor & 7,678 & $-4,844$ & -63 & 10,033 & 1,858 & 19 & 10,949 & $-6,752$ & -62 \\
\hline $\begin{array}{l}\text { Land-- } \\
\text { middle }\end{array}$ & 6,211 & 15,205 & 245 & 6,525 & 4,508 & 69 & 13,275 & 20,542 & 155 \\
\hline Land-rich & 7,973 & 1,449 & 18 & 8,932 & 7,476 & 84 & 11,535 & $-6,032$ & -52 \\
\hline $\begin{array}{l}\text { Education- } \\
\text { none }\end{array}$ & 5,691 & 11,074 & 195 & 7,902 & 16,350 & 207 & 11,737 & 51,903 & 442 \\
\hline $\begin{array}{l}\text { Education- } \\
\text { primary }\end{array}$ & 6,595 & 9176 & 139 & 7,526 & -844 & -11 & 9,914 & 12,194 & 123 \\
\hline $\begin{array}{l}\text { Education- } \\
\text { secondary }\end{array}$ & 8,029 & 5,481 & 68 & 9,218 & $-6,063$ & -66 & 12,280 & 27,802 & -226 \\
\hline
\end{tabular}


Table B.5. Impact of FFSs in Tanzania

\begin{tabular}{|c|c|c|c|c|c|c|c|c|c|}
\hline & $\begin{array}{c}\text { Crop } \\
\text { production } \\
\text { (TAS/acre) }\end{array}$ & ATT & $\begin{array}{c}\% \\
\text { change }\end{array}$ & $\begin{array}{l}\text { Livestock } \\
\text { income } \\
\text { (TAS) }\end{array}$ & ATT & $\begin{array}{c}\% \\
\text { change }\end{array}$ & $\begin{array}{l}\text { Agricultural } \\
\text { income per } \\
\text { capita (TAS) }\end{array}$ & ATT & $\begin{array}{c}\% \\
\text { change }\end{array}$ \\
\hline & Before FFS & & & Before FFS & & & Before FFS & & \\
\hline $\begin{array}{l}\text { All FFS } \\
\text { members }\end{array}$ & 113,786 & 25,902 & 23 & 133,427 & 8,556 & 6 & 9,238 & 9,644 & 104 \\
\hline $\begin{array}{l}\text { Female- } \\
\text { headed } \\
\text { households }\end{array}$ & 160,329 & 88,714 & 55 & 137,859 & 2,476 & 2 & 19,710 & 30,536 & 155 \\
\hline $\begin{array}{l}\text { Male- headed } \\
\text { households }\end{array}$ & 106,339 & 24,724 & 23 & 132,704 & 10,610 & 8 & 7,568 & 7,910 & 105 \\
\hline Land-poor & 133,921 & $-16,619$ & -12 & 124,136 & 30,969 & 25 & 8,532 & 2,219 & 26 \\
\hline Land- middle & 122,555 & 58,879 & 48 & 144,509 & 87,484 & 61 & 10,441 & 10,306 & 99 \\
\hline Land-rich & 54,276 & 14,289 & 26 & 126,875 & 276,803 & 218 & 7,903 & 23,506 & 297 \\
\hline $\begin{array}{l}\text { Education- } \\
\text { none }\end{array}$ & 63,036 & 81,903 & 130 & 61,604 & 84,352 & 137 & 6,879 & 14,686 & 213 \\
\hline $\begin{array}{l}\text { Education- } \\
\text { primary }\end{array}$ & 109,258 & 16,001 & 15 & 108,567 & -204 & 0 & 8,957 & 8,610 & 96 \\
\hline $\begin{array}{l}\text { Education- } \\
\text { secondary }\end{array}$ & 180,281 & 19,059 & 11 & 364,790 & 904,203 & 248 & 13,199 & $-11,565$ & -88 \\
\hline
\end{tabular}

Table B.6. Impact of FFSs in Uganda

\begin{tabular}{|c|c|c|c|c|c|c|c|c|c|}
\hline & $\begin{array}{c}\text { Crop } \\
\text { production } \\
\text { (UGX/acre) }\end{array}$ & ATT & & $\begin{array}{c}\text { Live-stock } \\
\text { income } \\
\text { (UGX) }\end{array}$ & ATT & & $\begin{array}{c}\text { Agricultural } \\
\text { income per capita } \\
\text { (UGX) }\end{array}$ & ATT & \\
\hline & Before FFS & & & Before FFS & & & Before FFS & & \\
\hline $\begin{array}{l}\text { All FFS } \\
\text { members }\end{array}$ & 203,010 & $-19,610$ & -10 & 366,093 & 87,610 & 24 & 34,057 & 5,998 & 18 \\
\hline $\begin{array}{l}\text { Female- } \\
\text { headed } \\
\text { households }\end{array}$ & 118,618 & 120,773 & 102 & 183,792 & 343557 & 187 & 73,568 & 26,770 & 36 \\
\hline $\begin{array}{l}\text { Male- headed } \\
\text { households }\end{array}$ & 217,151 & $-90,330$ & -42 & 399,779 & 215,945 & 54 & 27,401 & 11,318 & 41 \\
\hline Land-poor & 160,595 & $-89,278$ & -56 & 363,241 & 278,431 & 77 & 12,163 & -510 & -4 \\
\hline Land- middle & 207,901 & 217,376 & 105 & 371,857 & 300,159 & 81 & 39,690 & 31,306 & 79 \\
\hline Land-rich & 232,271 & 153,213 & -66 & 362,827 & $-27,045$ & -7 & 46,127 & 11,755 & -25 \\
\hline $\begin{array}{l}\text { Education- } \\
\text { none }\end{array}$ & 178,116 & 204,264 & 115 & 158,596 & $-2,755$ & -2 & 17,827 & 7,704 & 43 \\
\hline $\begin{array}{l}\text { Education- } \\
\text { primary }\end{array}$ & 212,637 & 61,183 & 29 & 317,468 & 210,561 & 66 & 41,398 & 46,994 & 114 \\
\hline $\begin{array}{l}\text { Education-- } \\
\text { secondary }\end{array}$ & 216,354 & 63,183 & 29 & 420,657 & $-88,535$ & -21 & 28,449 & 19,911 & -70 \\
\hline
\end{tabular}


Table B.7. Impact of FFSs, all countries

\begin{tabular}{|c|c|c|c|c|c|c|c|c|c|}
\hline & $\begin{array}{c}\text { Crop } \\
\text { production } \\
\text { (US\$/acre) }\end{array}$ & ATT & $\%$ change & $\begin{array}{c}\text { Livestock } \\
\text { income } \\
\text { (US\$) }\end{array}$ & ATT & $\%$ change & $\begin{array}{l}\text { Agricultural } \\
\text { income per } \\
\text { capita(US\$) }\end{array}$ & ATT & $\%$ change \\
\hline & Before FFS & & & Before FFS & & & Before FFS & & \\
\hline $\begin{array}{l}\text { All FFS } \\
\text { members }\end{array}$ & 94.1 & 29.9 & 32 & 276 & 39.4 & & 75.2 & 45.7 & 61 \\
\hline $\begin{array}{l}\text { Female- } \\
\text { headed } \\
\text { households }\end{array}$ & 85.4 & 117.8 & 138 & 236 & 55.3 & 23 & 100.8 & 188.9 & 187 \\
\hline $\begin{array}{l}\text { Male- } \\
\text { headed } \\
\text { households }\end{array}$ & 95.5 & 14.3 & 15 & 283 & -3 & -1 & 70.8 & -26.3 & -37 \\
\hline Land-poor & 98.1 & -43.2 & -44 & 198 & 85.6 & 43 & 83.4 & 29.8 & 36 \\
\hline $\begin{array}{l}\text { Land-- } \\
\text { middle }\end{array}$ & 88.1 & 94.5 & 107 & 187 & 40.2 & 21 & 96.2 & 22.9 & 24 \\
\hline Land-rich & 96.3 & -8.5 & -9 & 453 & 21 & 5 & 44 & 0.04 & 0 \\
\hline $\begin{array}{l}\text { Education- } \\
\text { none }\end{array}$ & 68.6 & 173.4 & 253 & 191 & 79.9 & 42 & 78.5 & 176.1 & 224 \\
\hline $\begin{array}{l}\text { Education- } \\
\text { primary }\end{array}$ & 89.1 & 19.4 & 22 & 222 & 17.7 & 8 & 59.5 & 62.3 & 105 \\
\hline $\begin{array}{l}\text { Education- } \\
\text { secondary }\end{array}$ & 115.7 & 34.9 & 30 & 357 & 66.8 & 19 & 101 & -158.9 & -157 \\
\hline
\end{tabular}




\section{REFERENCES}

Abadie, A., and G. Imbens. 2002. Simple and bias-corrected matching estimators. Department of Economics. Berkeley: University of California

Abadie, A., and G. Imbens. 2006. Large sample properties of matching estimators for average treatment effects. Econometrica 74 (1): 235-267. 2007. Bias corrected matching estimators for average treatment effects. Working paper, Harvard University Department of Economics, Cambridge, MA, U.S.A.

Alokit-Olaunah, C. 2006. Baseline survey for assessing socioeconomic characteristics of farmers participating in farmer field schools of Busia, Kabermaido, and Soroti districts of eastern Uganda. Nairobi: Food and Agriculture Organization of the United Nations.

Alston, J.M., and P.G. Pardey. 2001. Attribution and other problems in assessing the returns to agricultural R\&D. Agricultural Economics 25: 141-152.

Anandajayasekeram, P., K. Davis, and S. Workneh. 2007. Farmer field schools: An alternative to existing extension systems? Experience from eastern and southern Africa. Journal of International Agricultural and Extension Education 14 (1): 81-93.

Anderson, J.R. 2007. Agricultural advisory services (background paper to "Science and technology for pro-poor growth" chapter). In World development report 2008, ed. D. Byerlee. Washington, D.C: World Bank.

Benin, S., E. Nkonya, G. Okecho, J. Pender. S. Nahdy, S. Mugarura, E. Kato, and G. Kayobyo. 2007. Assessing the impact of the National Agricultural Advisory Services (NAADS) in the Uganda rural livelihoods. Discussion Paper 00724. Washington, D.C.: International Food Policy Research Institute.

Bentley, J.W., O. Barea, S. Priou, H. Equise, and G. Thiele. 2007. Comparing farmer field schools, community workshops, and radio: Teaching Bolivian farmers about bacterial wilt of potato. Journal of International Agricultural and Extension Education 14 (3): 45-61.

Birkhaeuser, D., R.E. Evenson, and G. Feder. 1991. The economic impact of agricultural extension: A review. Economic Development and Cultural Change 39 (3): 607-640.

Birner, R., K. Davis, J. Pender, E. Nkonya, P. Anandajayasekeram, J. Ekboir, A. Mbabu, D.J. Spielman, D. Horna, D.S. Benin, and W. Kisamba-Mugerwa. 2006. From "best practice" to "best fit": A framework for analyzing pluralistic agricultural advisory services worldwide. International Service for National Agricultural Research Discussion Paper 5. Washington, D.C.: International Food Policy Research Institute.

Braun, A., J. Jiggins, N. Röling, H. van den Berg, and P. Snijders. 2006. A global survey and review of farmer field school experiences. Nairobi: International Livestock Research Institute.

Christoplos, I., and A. Kidd. 2000. Guide for monitoring, evaluation, and joint analyses of pluralistic extension support. Lindau: Neuchâtel Group.

Curry, J. 1996. Gender and livestock in African production systems: An introduction. Human Ecology 24(2): 149160.

David, S. 2007. Learning to think for ourselves: Knowledge improvement and social benefits among farmer field school participants in Cameroon. Journal of International Agricultural and Extension Education 14 (2): $35-49$.

Davis, K. 2004. Technology dissemination among small-scale farmers in Meru Central District of Kenya: Impact of group participation. Unpublished doctoral dissertation, University of Florida, Gainesville, Florida.

. 2006. Farmer field schools: A boon or bust for extension in Africa? Journal of International Agricultural and Extension Education 13 (1): 91-97.

Davis, K., and E. Nkonya. 2008. Developing a methodology for assessing the impact of farmer field schools in East Africa. Proceedings of the 24th Annual Meeting of the Association for International Agricultural and 
Extension Education (AIAEE), 93-99.College Station, Texas: Association for International Agricultural and Extension Education.

Davis, K., and N. Place. 2003. Non-governmental organizations as an important actor in agricultural extension in semiarid East Africa. Journal of International Agricultural and Extension Education 10 (1): 31-36.

Dehejia, R., and S. Wahba. 2002. Propensity score matching methods for non-experimental causal studies. Review of Economics and Statistics 84 (1): 151-161.

Duflo, E., R. Glennerster, and M. Kremer. 2006. Using randomization in development economics research: A toolkit. Working Paper 138. Cambridge: Harvard University Center for International Development.

Erbaugh, J.M., J. Donnermeyer, and P. Kibwika. 2001. Evaluating farmers' knowledge and awareness of integrated pest management (IPM): Assessment of the IPM Collaborative Research Support Program in Uganda. Journal of International Agricultural and Extension Education 8 (1): 47-53.

FAO (Food and Agriculture Organization of the United Nations). 1997. Research and extension: A gender perspective. 〈http://www.fao.org/focus/e/women/extens-e.htm〉. Accessed November 1, 2007.

2001. Progress report-2001. Farmer innovation and new technology options for food production, income generation, and combating desertification. KEN/99/200. Nairobi: FAO.

FAO/KARI/ILRI (FAO/Kenya Agricultural Research Institute/International Livestock Research Institute). 2003. Farmer field schools: The Kenyan experience. Report of the farmer field school stakeholders' forum, March 27, ILRI, Nairobi, Kenya.

Feder, G., R. Murgai, and J.B. Quizon. 2004a. Sending farmers back to school: The impact of FFS in Indonesia. Review of Agricultural Economics 26 (1): 45-62.

2004b. The acquisition and diffusion of knowledge: The case of pest management training in farmer field schools, Indonesia. Journal of Agricultural Economics 55 (2): 217-239.

Feder, G., Just, R.E., Zilberman, D. 1985. Adoption of agricultural innovations in developing countries: A survey. Economic Development and Cultural Change 33, 255-297.

Food and Agriculture Organization. 2005. Participatory monitoring and evaluation: Kenya project planning workshop. December 13-15, Bungoma, Kenya.

Gockowski, J., C. Asamoah, S. David, G.B. Nkamleu, I. Gyamfi, S. Agordorku, and M.A. Kuti. 2006. An evaluation of farmer field school training on the livelihoods of cocoa farmers in Atwima District, Ashanti Region, Ghana. Sustainable Tree Crops Program Working Papers Series 1. Ibadan, Nigeria: International Institute for Tropical Agriculture.

Godtland, E., E. Sadoulet, A. de Janvry, R. Murgai, and O. Ortiz. 2004. The impact of FFS on knowledge and productivity: A study of potato farmers in the Peruvian Andes. CUDARE Working Paper 963. Department of Agricultural and Resource Economics, University of California, Berkeley, U.S.A.

Gould, W.W., and W.H. Rogers. 1991. Summary of tests of normality. Stata Technical Bulletin 3: 20-23. Reprinted in Stata Technical Bulletin Reprints 1: 106-110.

Haug, R. 1999. Some leading issues in agricultural extension: A literature review. Journal of Agricultural Education and Extension 5 (4): 263-274.

Heckman, J., H. Ichimura, J. Smith, and P. Todd. 1998. Characterizing selection bias using experimental data. Econometrica 66: 1017-1099.

IFAD (International Fund for Agricultural Development). 1998. Report and recommendation of the president to the executive board on a proposed technical assistance grant to the Food and Agricultural Organization of the United Nations for the East African pilot project for farmer field schools in Kenya, the United Republic of Tanzania, and Uganda. Rome: IFAD.

Imbens, G.M., and J.M. Wooldridge. 2008. Recent developments in the econometrics of program evaluation. Working Paper 14251. Cambridge, MA, U.S.A.: National Bureau of Economic Research. 
InterAcademy Council. 2004. Realizing the promise and potential of African agriculture: Science and technology strategies for improving agricultural productivity and food security in Africa. Amsterdam: InterAcademy Council.

Jagger, P., and J. Pender. 2006. Influence of programs and organizations on the adoption of sustainable land management technologies in Uganda. In Strategies for sustainable land management in the East African highlands, ed. J. Pender, F. Place, and S. Ehui, 277-308. Washington, D.C.: International Food Policy Research Institute.

Kimani, M., and A. Mafa. n.d. The East African Sub-Regional Pilot Project for Farmer Field Schools Integrated Production and Pest Management (IPPM FFS), Kenya - Case Study Report. London: Darwin Initiative and BMZ/GTZ. 21 pp.

Leeuwis, C., N. Röling, and G. Bruin. 1998. Can the farmer field school replace the T\&V system of extension in Sub-Saharan Africa? Paper presented at the 15th International Symposium of the Association for Farming Systems Research-Extension, November 30-December 4, Pretoria, South Africa.

Mukherjee, C., H. White, and M. Wuyts. 1998. Econometrics and data analysis for developing countries. London: Routledge.

Nkuba, J.M., J. Thomas, and D. Duveskog. 2007. IFAD TAG-FFS baseline report: Bukoba, Kagera Region, Tanzania. GCP/RAF/399/RFA. Nairobi: Food and Agriculture Organization of the United Nations.

Odendo, M., D. Duveskog, and G. Khisa. 2006. Farmers' welfare status, production practices, access to agricultural services, and empowerment in western Kenya. Report of a baseline survey carried out in the "Expansion of Farmer Field School Project" sites in western Kenya. Nairobi: Food and Agriculture Organization of the United Nations.

Ortiz, O., K.A. Garrett, J.J. Heath, R. Orrego, and R.J. Nelson. 2004. Management of potato blight in the Peruvian highlands: Evaluating the benefits of farmer field schools and farmer participatory research. Plant Disease 88: 565-571.

Place, F., G. Kariuki, J. Wangila, P. Kristjanson, A. Makauki, and J. Ndubi. 2002. Assessing the factors underlying differences in group performance: Methodological issues and empirical findings from the highlands of central Kenya. CAPRi Working Paper 25. Washington, D.C.: International Food Policy Research Institute.

Platteau, J. 2004. Monitoring elite capture in community-driven development. Development and Change 35 (2): 223-246.

Purcell, D.L., and J.R. Anderson. 1997. Agricultural extension and research: Achievements and problems in national systems. Washington, D.C.: World Bank.

Rola, A.C., S.B. Jamias, and J.B. Quizon. 2002. Do FFS graduates retain and share what they learn? An investigation in Iloilo, Philippines. Journal of Agricultural and Extension Education 9 (1): 65-75.

Rosenbaum, P.R., and D.B. Rubin. 1983. The central role of the propensity score in observational studies for causal effects. Biometrika 70 (1): 41-55.

Rutatora, D., and A. Mattee. 2001. Major agricultural extension providers in Tanzania. African Study Monograph 22 (4):155-173.

Saito, A.K., H. Mekonnen, and D. Spurling. 1994. Raising the productivity of women farmers in Sub-Saharan Africa. World Bank Discussion Paper 230, Africa Technical Department Series. Washington, D.C.: World Bank.

Salter, A.J., and B.R. Martin. 2001. The economic benefits of publicly funded basic research: A critical review. Research Policy 30: 509-532.

Smale, M., L. Diakite, A. Sidibe, M. Grum, and H. Jones. 2008. An econometric analysis of the impact of farmer participation in diversity field fora in Mali. Unpublished manuscript, International Food Policy Research Institute, Washington, D.C.

Smith, J.A., and P.E. Todd. 2001. Reconciling conflicting evidence on the performance of propensity-score matching methods. American Economics Association (AEA) Papers and Proceedings 91 (2). 112-118. 
2005. Does matching overcome LaLonde's critique of nonexperimental estimators? Journal of Econometrics 125 (1-2): 305-353.

Stringfellow, R., J. Coulter, T. Lucey, C. McKone, and A. Hussain. 1997. Improving the access of smallholders to agricultural services in Sub-Saharan Africa: Farmer cooperation and the role of the donor community. Natural Resource Perspectives 20. London: Overseas Development Institute.

Thornton, P.K., R.L.Kruska, N.Henninger, P.M.Kristjanson, R.S.Reid, F.Atieno, A.N.Odero and T.Ndegwa. 2002. Mapping Poverty and Livestock in the Developing World. International Livestock Research Institute. Online at: http://www.ilri.org/InfoServ/Webpub/Fulldocs/Mappoverty/index.htm.

Tripp, R., M. Wijeratne, and V.H. Piyadasa. 2005. What should we expect from FFS? A Sri Lanka case study. World Development 33 (10): 1705-1720.

van den Berg, H. 2004. IPM FFS: A synthesis of 25 impact evaluations. Report prepared for the Global IPM Facility. Wageningen: The Netherlands.

van den Berg, H., and J. Jiggins. 2007. Investing in farmers - the impacts of farmer field schools in relation to integrated pest management. World Development 35 (4): 663-686.

Yamazaki, S., and B.P. Resosudarmo. 2006. Does sending farmers back to school have an impact? A spatial econometrics approach. Paper presented at the International Association of Agricultural Economists Conference, August 12-18, Brisbane, Australia. 





\section{RECENT IFPRI DISCUSSION PAPERS}

For earlier discussion papers, please go to http://www.ifpri.org/publications/results/taxonomy\%3A468. All discussion papers can be downloaded free of charge.

991. Exploring the long-term impact of development interventions within life-history narratives in rural Bangladesh. Peter Davis, 2010.

990. The costs and benefits of duty-free, quota-free market access for poor countries: Who and what matters? Antoine Bouët, David Laborde Debucquet, Elisa Dienesch, and Kimberly Elliot, 2010.

989. Mountains, global food prices, and food security in the developing world. Kamiljon T. Akramov, Bingxin Yu, and Shenggen Fan, 2010.

988. Examining the dynamic relationship between spot and future prices of agricultural commodities. Manuel Hernandez and Maximo Torero, 2010.

987. Dynamic agricultural supply response under economic transformation: A case study of Henan Province. Bingxin Yu, Fengwei Liu, and Liangzhi You, 2010.

986. $R \& D$ investment in national and international agricultural research: An ex-ante analysis of productivity and poverty impact. Alejandro Nin Pratt and Shenggen Fan, 2010

985. Food security and economic development in the Middle East and North Africa: Current state and future perspectives. Clemens Breisinger, Teunis van Rheenen, Claudia Ringler, Alejandro Nin Pratt, Nicolas Minot, Catherine Aragon, Bingxin Yu, Olivier Ecker, and Tingju Zhu, 2010.

984. Improving resource allocation and incomes in Vietnamese agriculture: A case study of farming in the Dong Nai River Basin. Joshua Dewbre, 2010.

983. Positional spending and status seeking in rural China. Philip H. Brown, Erwin Bulte, and Xiaobo Zhang, 2010.

982. Assessing food security in Yemen: An innovative integrated, cross-sector, and multilevel approach. Olivier Ecker, Clemens Breisinger, Christen McCool, Xinshen Diao, Jose Funes, Liangzhi You, and Bingxin Yu, 2010.

981. Long-term impact of investments in early schooling: Empirical evidence from rural Ethiopia. Subha Mani, John Hoddinott, and John Strauss, 2010.

980. Infrastructure and cluster development: A case study of handloom weavers in Ethiopia. Gezahegn Ayele, Lisa Moorman, Kassu Wamisho, and Xiaobo Zhang, 2010.

979. Country-level impact of global recession and China's stimulus package: A general equilibrium assessment. Xinshen Diao, Yumei Zhang, and Kevin Z. Chen, 2010.

978. Emergence of Sri Lanka in European fish trade: Is there cause for concern in the Lake Victoria Region (East Africa)? Andrew Muhammad and Guyslain Ngeleza, 2010.

977. China has reached the Lewis Turning Point. Xiaobo Zhang, Jin Yang, and Shenglin Wang, 2010.

976. The medium-term impact of the primary education stipend in rural Bangladesh. Bob Baulch, 2010.

975. A review of empirical evidence on gender differences in nonland agricultural inputs, technology, and services in developing countries. Amber Peterman, Julia Behrman, and Agnes Quisumbing, 2010.

974. An experiment on the impact of weather shocks and insurance on risky investment. Ruth Vargas Hill and Angelino Viceisza, 2010.

973. Engendering agricultural research. Ruth Meinzen-Dick, Agnes Quisumbing, Julia Behrman, Patricia Biermayr-Jenzano, Vicki Wilde, Marco Noordeloos, Catherine Ragasa, Nienke Beintema, 2010.

972. Sarpanch Raj: Is the president all powerful? The case of village councils in India. Nethra Palaniswamy, 2010.

971. Asset versus consumption poverty and poverty dynamics in the presence of multiple equilibria in rural Ethiopia. Lenis Saweda O. Liverpool and Alex Winter-Nelson, 2010.

970. Poverty status and the impact of social networks on smallholder technology adoption in rural Ethiopia. Lenis Saweda O. Liverpool and Alex Winter-Nelson, 2010. 


\section{INTERNATIONAL FOOD POLICY RESEARCH INSTITUTE}

\section{www.ifpri.org}

IFPRI HEADQUARTERS

2033 K Street, NW

Washington, DC 20006-1002 USA

Tel.: +1-202-862-5600

Fax: +1-202-467-4439

Email: ifpri@cgiar.org

IFPRI ADDIS ABABA

P. O. Box 5689

Addis Ababa, Ethiopia

Tel.: +251116463215

Fax: +251116462927

Email: ifpri-addisababa@cgiar.org

IFPRI NEW DELHI

CG Block, NASC Complex, PUSA

New Delhi 110-012 India

Tel.: 9111 2584-6565

Fax: 9111 2584-8008 / 2584-6572

Email: ifpri-newdelhi@cgiar.org 